\title{
Salt Sensitive Tet-Off-Like Systems to Knockdown Primordial Germ Cell Genes for Repressible Transgenic Sterilization in Channel Catfish, Ictalurus punctatus
}

\author{
Hanbo Li ${ }^{1,+}$, Baofeng Su ${ }^{1,2,+}$, Guyu Qin ${ }^{1}$, Zhi Ye ${ }^{1}$, Ahmed Alsaqufi ${ }^{1,3}$, Dayan A. Perera ${ }^{1,4}$, \\ Mei Shang ${ }^{1,2}$, Ramjie Odin ${ }^{1}$, Khoi Vo ${ }^{1}$, David Drescher ${ }^{1}$, Dalton Robinson ${ }^{1}$, Dan Zhang ${ }^{1}$, \\ Nermeen Abass ${ }^{1,5}$ and Rex A. Dunham ${ }^{1, *}$ \\ 1 School of Fisheries, Aquaculture and Aquatic Sciences, Auburn University, Auburn, AL 36849, USA; \\ hz10026@tigermail.auburn.edu (H.L.); subaofeng@hrfri.ac.cn (B.S.); gzq0002@tigermail.auburn.edu (G.Q.); \\ zzy0008@tigermail.auburn.edu (Z.Y.); asa0014@tigermail.auburn.edu (A.A.); dperera@wvstateu.edu (D.A.P.); \\ mzs0040@tigermail.auburn.edu (M.S.); ryo0001@tigermail.auburn.edu (R.O.); \\ kmv0005@tigermail.auburn.edu (K.V.); dmd0028@tigermail.auburn.edu (D.D.); \\ dar0037@tigermail.auburn.edu (D.R.); dzz0007@tigermail.auburn.edu (D.Z.); nyy0001@auburn.edu (N.A.) \\ 2 National and Local United Engineering Laboratory for Freshwater Fish Breeding, \\ Heilongjiang River Fisheries Research Institute, Chinese Academy of Fisheries Sciences, \\ Harbin 150070, China \\ 3 Department of Aquaculture and Animal, King Faisal University, Al Ahsa 31982, Saudi Arabia \\ 4 Research and Development Corporation, Gus R. Douglass Institute, West Virginia State University, \\ WV 25112, USA \\ 5 Department of Agricultural Botany, Faculty of Agriculture Saba-Basha, Alexandria University, \\ Alexandria City, P.O. Box 2153, Egypt \\ * Correspondence: dunhara@auburn.edu; Tel.: +334-8442345 \\ + These authors contributed equally to this work.
}

Academic Editors: Allen Place, Rosemary Jagus, Joy Watts and Paul Long

Received: 1 April 2017; Accepted: 25 May 2017; Published: 31 May 2017

\begin{abstract}
Repressible knockdown approaches were investigated for transgenic sterilization in channel catfish, Ictalurus punctatus. Two primordial germ cell (PGC) marker genes, nanos and dead end, were targeted for knockdown, and an off-target gene, vasa, was monitored. Two potentially salt sensitive repressible promoters, zebrafish adenylosuccinate synthase 2 (ADSS) and zebrafish racemase (Rm), were each coupled with four knockdown strategies: ds-sh RNA targeting the $5^{\prime}$ end (N1) or $3^{\prime}$ end (N2) of channel catfish nanos, full-length cDNA sequence of channel catfish nanos for overexpression (cDNA) and ds-sh RNA targeting channel catfish dead end (DND). Each construct had an untreated group and treated group with sodium chloride as the repressor compound. Spawning rates of full-sibling $\mathrm{P}_{1}$ fish exposed or not exposed to the constructs as treated and untreated embryos were $93 \%$ and $59 \%$, respectively, indicating potential sterilization of fish and repression of the constructs. Although the mRNA expression data of PGC marker genes were inconsistent in $\mathrm{P}_{1}$ fish, most $\mathrm{F}_{1}$ individuals were able to downregulate the target genes in untreated groups and repress the knockdown process in treated groups. The results indicate that repressible transgenic sterilization is feasible for reproductive control of fish, but more data from $\mathrm{F}_{2}$ or $\mathrm{F}_{3}$ are needed for evaluation.
\end{abstract}

Keywords: transgenic sterilization; repressible by sodium chloride; PGC migration; RNAi 


\section{Introduction}

Since the commercialization of AquaBounty Technologies's AquAdvantage ${ }^{\circledR}$ Salmon [1], the control of escapement of transgenic offspring has received as much attention as the advantages of transgenic fish. A major concern regarding the use of transgenic fish is potential ecological impact from escapees or released individuals on natural populations [2,3]. All transgenic organisms should be adequately confined both physically and genetically to minimize environmental risk.

Physical confinement cannot guarantee that transgenic fish will never establish in the wild since the possibility of theft, human error and catastrophic events could compromise the physical confinement, leading to escape of transgenic animals from aquaculture systems [4]. A genetic confinement system that requires human intervention to allow brood stock production and fertility overcomes these weaknesses. Obviously, the use of both and redundant systems further decreases the risk of establishment of transgenes. If used outside their native geographical range, all species are potentially invasive. Different permutations of transgenic sterilization can potentially be used to prevent spread of invasive species.

The embryonic precursors of the gametes are primordial germ cells (PGCs), their origin is distant from the developmental site of the gonads, and they must migrate to the embryo's genital ridge [5]. PGCs will eventually die without migration, but the death has no effect on somatic development. As a result, disrupting the migration of PGCs is a potentially viable approach to complete transgenic sterilization. In zebrafish (Danio rerio), a number of genetic markers are associated with PGC migration, such as vasa, nanos (nos), askopos, dead end and dazl. Knock out of those markers genes can prevent or disrupt the migration of PGCs [6-10]. Prevention of PGC migration invariably produces sterile fish [8-12].

Nanos is essential for proper migration and survival of PGCs in zebrafish $[5,6]$. Although the formation of PGCs does not require nanos activity, PGCs with nanos deficiency demonstrate abnormal conditions such as lack of colonization in the gonad, premature activation of germ cell markers, abnormal morphology and expression of mRNAs that are normally expressed in the soma. Vasa is an RNA binding protein with an RNA dependent helicase. Long-term and continual expression in the germ line makes vasa a unique PGC marker $[5,13,14]$. As a PGC marker, the role and functions of vasa are not as conserved as other markers as it may have evolved to have different functions in different species, which may explain its longer duration of expression compared to other PGC markers $[9,15]$. In zebrafish, vasa encodes an RNA helicase, and is essential for the assembly of the germplasm and the migration of PGCs [16]. Another function of vasa is to overcome the repressive effect of nanos translational control element, an evolutionarily conserved dual stem-loop structure in the $3^{\prime}$ UTR, which acts independently of the localization signal to repress translation of nanos mRNA [17]. Dead end protein is a RNA-binding factor that positively regulates gene expression by prohibiting micro RNA (miRNA)-mediated gene suppression [18]. In zebrafish, miR-430 is a miRNA responsible for the downregulation of several hundred targeted mRNAs in soma cells including nanos. By binding to U-rich sequence elements in $3^{\prime}$ UTR of those mRNAs and inhibiting the activity of miR-430, dead end protein protects those mRNAs from degradation in the germ cells, thus, relieving miRNA repression in germline cells by blocking the accessibility of target mRNAs to miRNAs. As the first factor to play a specific role in the initiation of PGC mobility, knockdown of dead end terminates the initial migration step of PGCs, dorsal movement within the deep blastoderm [12].

RNAi is frequently used in molecular biotechnology for targeted gene knockdown. Different strategies such as double-stranded RNA (dsRNA), short hairpin RNA (shRNA), miRNA and small interfering RNA (siRNA) can be applied to achieve the goal [19]. When exogenous RNA, which is synthesized with a sequence complementary to a gene of interest, is expressed in vivo and the RNAi pathway activated, the target gene is silenced [20]. Unlike the use of dsRNA and shRNA for RNAi, overexpression of a target gene via full-length cDNA is another option to inhibit target genes. This process should trigger a negative feedback loop or have undesired malicious effects, leading to disruption of the stoichiometry of the protein complex and loss of function. In the case of the negative 
feedback loop, the excess nanos cDNA would be detected and the response would be the interruption of nanos mRNA transcription or protein translation. The effect of the response is the downregulation of nanos expression or degradation of nanos protein, resulting in nanos knockdown.

Function of the bone morphogenetic protein 2 (BMP-2) gene in zebrafish, common carp and channel catfish has been successfully disrupted using the cDNA overexpression approach [21]. Bernick et al. [22] overexpressed Unc-45b in zebrafish embryos, which resulted in defective thick filament organization. Overexpression could complement loss-of-function screens, and has dominant effects [23].

Modified Tet-off system has been applied to produce repressible transgenic sterile fish and oysters [21], although these systems have yet to be shown $100 \%$ effective or commercially feasible. Theoretically, the Tet-off system should be an effective repressible sterility system for preventing the establishment of feral populations of transgenic animals or exotic species [24]; however, the antibiotic repressors used in the system, tetracycline and doxycycline, are expensive when used in large-scale applications. In addition, accumulation or release of large amounts of antibiotics may result in antibiotic resistance of pathogens in the aquaculture environment, as well as the presence of antibiotics in drinking water. Additionally, the Tet-off transgenes contain small viral sequences that might be negatively perceived by consumers. Environmentally friendly and efficient Tet-off-like systems are needed, and promoters that can be repressed by non-antibiotic chemicals are preferred in the new systems.

Sodium chloride based Tet-off like systems could be such a system. Channel catfish embryos can tolerate 6 ppt of salinity in hatchery solutions [25], sodium chloride is commonly used in catfish culture to control disease and address water quality problems such as high nitrite [26]. It is inexpensive, easy to apply and when used in small quantities would cause no environmental damage. Thus, salt sensitive promoters could be viable replacements in Tet-off-like system, such as zebrafish adenylosuccinate synthase 2 (adss2) and racemace. These promoters were salt sensitive and can be repressed by $4 \mathrm{ppt} \mathrm{NaCl}$ in the laboratory [27], and thus, may be very appropriate for repressible sterilization in freshwater fish.

The knockdown constructs driven by a salt-sensitive promoter could be introduced into the fish. The PGC knockdown construct expresses, prevents PGC migration, and thus, sterilizes embryos not exposed to salt. These would be the production fish that are sterile and cannot reproduce if they were to escape into the natural environment. A portion of the embryos would be treated with salt, which should repress the knockdown construct and allow normal sexual development for the development of brood stock. If these fish escape, they can only produce sterile offspring, thus the transgene cannot become established in the receiving population and is present for one generation or less.

The objectives of the this study were to use transgenic technology to prevent PGC migration and gamete formation, leading to sterility in channel catfish, and then repress this process to produce fertile brood stock that generate sterile offspring. Specifically, zebrafish adss 2 and racemase promoters were evaluated to control the expression of ds-shRNA or cDNA constructs to knockdown targeted PGC migration related genes, nanos and dead end, and their repression evaluated by dosing with sodium chloride, towards the ultimate objective of successful repressible transgenic sterilization. Spawning success was measured in treated and untreated $\mathrm{P}_{1}$ brood stock, and PGC marker gene expression was determined in salt treated and untreated $\mathrm{P}_{1}$ and $\mathrm{F}_{1}$ generations.

\section{Results}

\subsection{Expression of Nanos, Vasa and Dead End in Channel Catfish Embryos}

At 48 and 120 hours post fertilization (hpf), nanos expression was declining relatively slowly, $-1.75 \mathrm{X}$ and $-4.21 \mathrm{X}$, respectively, relative to expression levels present at $24 \mathrm{hpf}$. The level of vasa was 7.36X lower at $48 \mathrm{hpf}$ than at $24 \mathrm{hpf}$, and was dramatically lower, $-61.11 \mathrm{X}$ at $120 \mathrm{hpf}$ compared to $24 \mathrm{hpf}$. Dead end was downregulated 3.35X at $48 \mathrm{hpf}$ and $12.91 \mathrm{X}$ at $120 \mathrm{hpf}$ compared to $24 \mathrm{hpf}$ (Figure 1). 


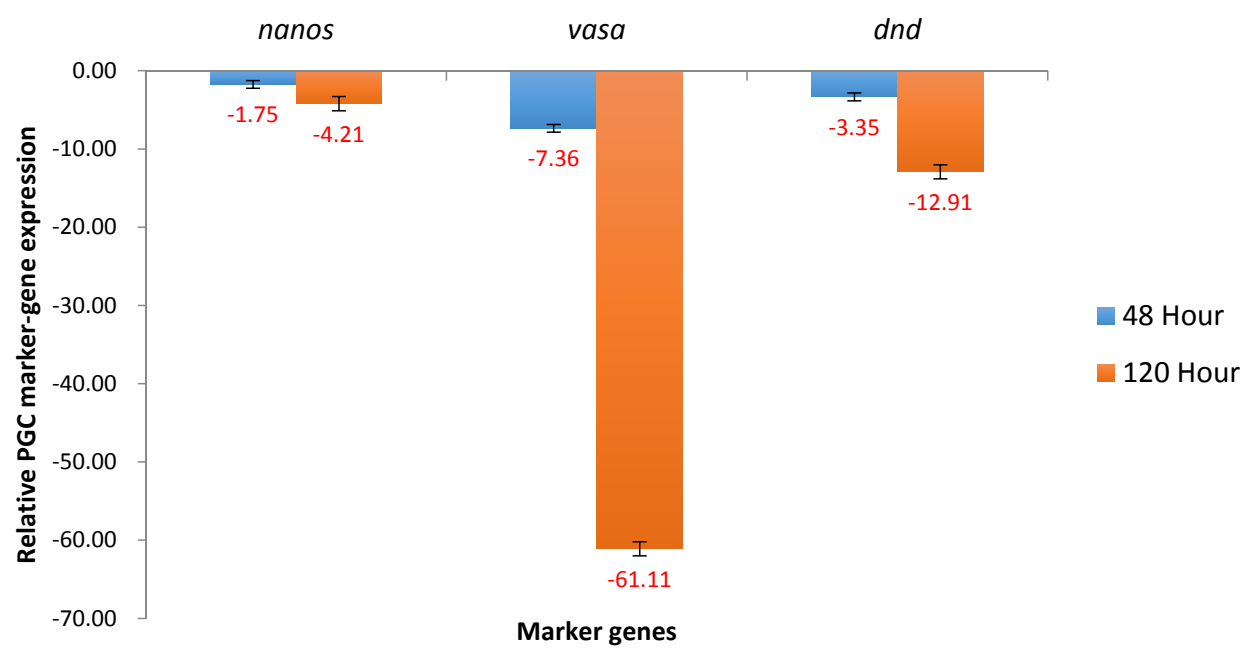

Figure 1. Relative expression of primordial germ cell (PGC) marker genes, nanos, vasa, and dead end $(d n d)$ in non-transgenic channel catfish (Ictalurus punctatus) embryos. The samples were analyzed at 24, 48 and $120 \mathrm{~h}$ post fertilization (hpf). Relative nanos, vasa and $d$ nd genes expression at $48 \mathrm{hpf}$ and $120 \mathrm{hpf}$ were expressed as fold change over $24 \mathrm{hpf}$ sample as normalized to change in the expression of $18 \mathrm{~s}$ control. All the red fold values numbers shown were significant at the level of $p<0.05$ using Pairwise Fixed Reallocation Randomization Test (PFRR) from REST (Relative Expression Software Tool).

\section{2. $P_{1}$ Spawning}

The overall spawning rates were significantly different $(p<0.05)$ for pooled untreated and treated groups, $59 \%$ and $93 \%$ (Table 1), respectively. $\mathrm{P}_{1}$ fish are always mosaic by tissue and by cells within tissues. When exogenous DNA is introduced to fish embryos, it replicates and is present in the cytoplasm for a long period during development before it is degraded. Therefore, transgenes that influence embryonic traits can have a phenotypic effect on the $F_{1}$ through exposure alone and do not necessarily need to be integrated for proof of principle. We have unpublished data, as well as published data [21], indicating phenotypic change in embryonic traits by exposure (electroporating) of the embryos to transgenes. Transfection rates are typically $20-50 \%[28,29]$ in $P_{1}$.

Table 1. Spawning rates of $\mathrm{P}_{1}$ female channel catfish (Ictalurus punctatus) electroporated with constructs designed to disrupt primordial germ cell migration and then either untreated or treated with sodium chloride expected to repress the expression of the transgene. Construct components were: ADSS, zebrafish adenylosuccinate Synthase 2 (adss2) promoter; RM, zebrafish racemase promoter; N1, 5' end ds-shRNA targeting channel catfish nanos gene; N2, 3' end ds-shRNA targeting channel catfish nanos gene; cDNA, full-length cDNA sequence of channel catfish nanos gene; DND, ds-shRNA targeting channel catfish dead end gene. Treated embryos were repressed with 4 ppt sodium chloride $(\mathrm{NaCl})$. * The difference between untreated and treated spawning rates of fish possessing that construct was significant $\left(p<0.05\right.$, Fisher's Exact Test). ${ }^{* *}$ Spawning rate of pooled untreated and treated P1 was different ( $p=0.0002$, Fisher's Exact Test). (Typical induced spawning rates of non-transgenic catfish unexposed to PGC knockdown constructs is approximately $90 \%$ [30]).

\begin{tabular}{ccccccc}
\hline \multirow{2}{*}{ Constructs } & \multicolumn{3}{c}{ Untreated } & \multicolumn{3}{c}{ Treated } \\
\cline { 2 - 7 } & Spawned & Total & \% & Spawned & Total & $\%$ \\
\hline ADSSN1 & 1 & 4 & 25 & - & - & - \\
ADSSN2 & 2 & 8 & 25 & 4 & 4 & 100 \\
ADSScDNA & 8 & 13 & 62 & 8 & 8 & 100 \\
ADSSDND & 6 & 8 & 75 & 5 & 5 & 100 \\
RMN1 & 7 & 9 & 78 & 8 & 8 & 100 \\
RMN2 & 6 & 8 & 75 & 8 & 10 & 80 \\
\hline
\end{tabular}


Table 1. Cont.

\begin{tabular}{ccccccc}
\hline \multirow{2}{*}{ Constructs } & \multicolumn{3}{c}{ Untreated } & \multicolumn{3}{c}{ Treated } \\
\cline { 2 - 7 } & Spawned & Total & $\%$ & Spawned & Total & $\%$ \\
\hline RMcDNA & 2 & 3 & 67 & 3 & 3 & 100 \\
RMDND & 2 & 5 & 40 & 2 & 3 & 67 \\
Total ${ }^{* *}$ & 34 & 58 & 59 & 38 & 41 & 93 \\
\hline
\end{tabular}

Fish from three, ADSSN1, ADSSN2 and RMDND, of the eight constructs in the untreated group had spawning rates lower than $50 \%$, while females from five of the eight constructs in the treated group had $100 \%$ spawning rates. There were significant differences $(p<0.05)$ between treated and untreated groups, for ADSSN2 construct as well as in pooled groups of all constructs.

When pooled by promoters, spawning rates in untreated groups and treated groups from the ADSS system had significant differences $(p<0.05)$ between transgenic treated and untreated groups. The ratio of treated spawning rate to untreated spawning rate was 1.94 (Table 2).

Table 2. Spawning rates of $\mathrm{P}_{1}$ female channel catfish (Ictalurus punctatus) electroporated with constructs designed to disrupt primordial germ cell migration and then either untreated or treated with sodium chloride expected to repress the expression of the transgene. Construct components were: ADSS, zebrafish adenylosuccinate Synthase 2 (adss2) promoter; RM, zebrafish racemase promoter; N1, 5' end ds-shRNA targeting channel catfish nanos gene; N2, 3' end ds-shRNA targeting channel catfish nanos gene; cDNA, full-length cDNA sequence of channel catfish nanos gene; DND, ds-shRNA targeting channel catfish dead end gene. Asterisk $\left(^{*}\right)$ behind the construct name means the difference untreated and treated spawning rates of fish possessing that construct was significant $(p<0.05$, Fisher's Exact Test). Treated embryos were repressed with 4 ppt sodium chloride $(\mathrm{NaCl})$. Ratio $\mathrm{T} / \mathrm{U}$ : treated spawning rate/untreated spawning rate.

\begin{tabular}{cccccccc}
\hline \multirow{2}{*}{ Constructs } & \multicolumn{3}{c}{ Untreated } & \multicolumn{3}{c}{ Treated } & \multirow{2}{*}{ Ratio of T/U } \\
\cline { 2 - 6 } & Spawned & Total & $\%$ & Spawned & Total & $\%$ & \\
\hline ADSS * & 17 & 33 & 52 & 17 & 17 & 100 & 1.94 \\
Rm & 17 & 25 & 68 & 21 & 24 & 88 & 1.29 \\
N1 & 8 & 13 & 62 & 8 & 8 & 100 & 1.61 \\
N2 & 8 & 16 & 50 & 12 & 14 & 86 & 1.72 \\
cDNA & 10 & 16 & 63 & 11 & 11 & 100 & 1.59 \\
DND & 8 & 13 & 62 & 7 & 8 & 82 & 1.32 \\
\hline
\end{tabular}

When pooling by knockdown strategy, spawning rates for untreated and treated groups of N2 had the best repression/knockdown efficiency compared to other strategies, with the efficiency ratio of 1.72 (Table 2).

\subsection{Real-Time Quantitative PCR Results for the $P_{1}$ and $F_{1}$ Generation Transgenic Channel Catfish}

\subsubsection{ADSS System}

Nanos of ADSSN1 was not significantly downregulated in $\mathrm{P}_{1}$ (Figure 2), for both treated and untreated groups. Treated and untreated groups showed similar off-target patterns of decreasing expression of dead end, from $6.82 \mathrm{X}$ to $3.48 \mathrm{X}$ for salt treated and $4.48 \mathrm{X}$ to $1.62 \mathrm{X}$ for the untreated. Differences between the salt treated and untreated group were minimal and inconsistent. There were no data generated for ADSSN1 in the $\mathrm{F}_{1}$ generation as no females were available to spawn in the treated group and the embryos from the untreated group were not transgenic (Table 2). 


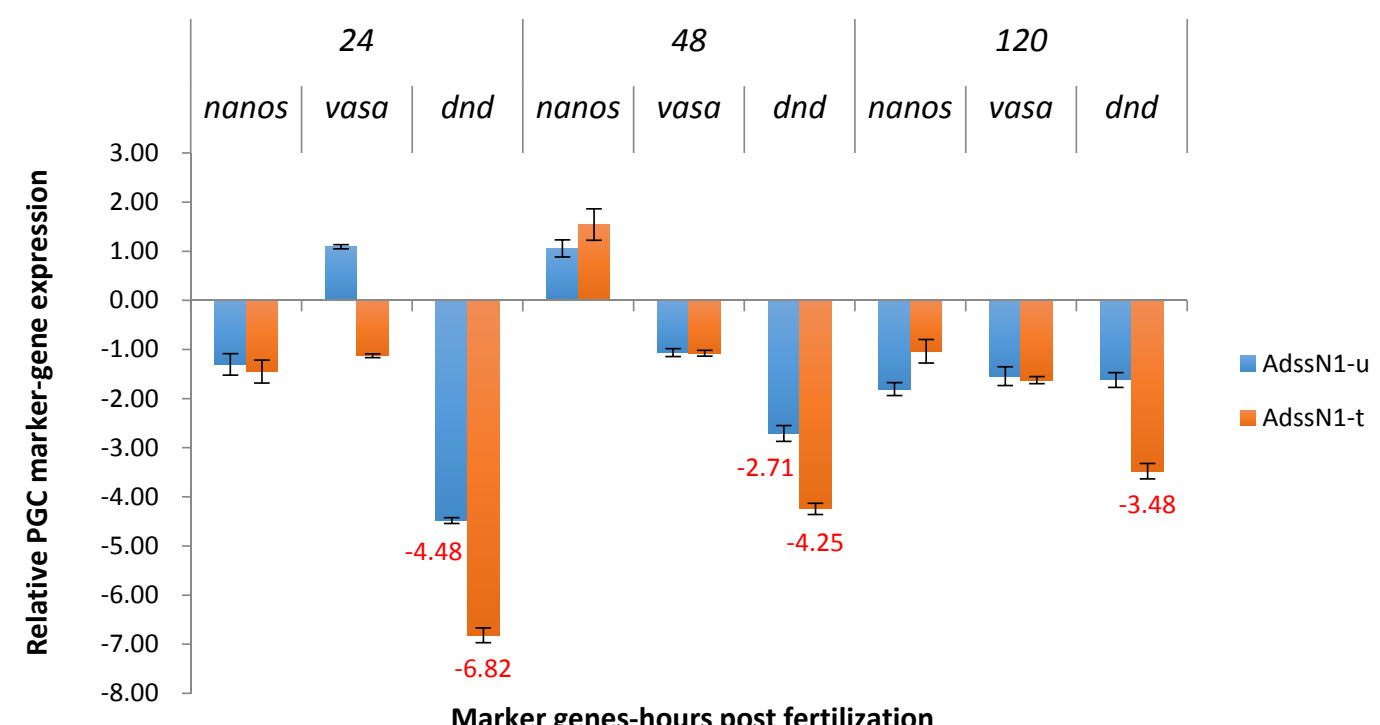

Figure 2. Relative expression of primordial germ cell (PGC) marker genes, nanos, vasa, and dead end $(d n d)$ in the treated and untreated groups exposed to zebrafish adenylosuccinate synthase 2 (adss2) gene (ADSS) promoter fused with 5' end shRNAi targeting channel catfish nanos gene (N1) as $\mathrm{P}_{1}$ ADSSN1 transgenic channel catfish (Ictalurus punctatus) embryos. $u$ represents untreated group, $t$ represents treated group. The treated group was incubated in $4 \mathrm{ppt}$ sodium chloride. The samples were analyzed at 24,48 and $120 \mathrm{~h}$ post fertilization (hpf), respectively. Relative nanos, vasa, and dead end (dnd) gene expression was expressed as fold change over non-transgenic control samples at the same time point. All the red fold values numbers shown were significantly different compared to non-transgenic control at the level of $p<0.05$ using Pairwise Fixed Reallocation Randomization Test (PFRR) from REST (Relative Expression Software Tool). Red X on the SE bar indicated the relative expression between the treated and untreated groups was significantly different from each other using PFRR.

ADSSN2 knocked down nanos in the $\mathrm{P}_{1}$ treated group from 1.98X to 2.91X at three time points (Figure 3a). Untreated ADSSN2 had variable effects on nanos at different time points as there was downregulation for nanos (2.32X) at $24 \mathrm{hpf}$, and upregulation for nanos (6.40X) at $120 \mathrm{hpf}$. Similar to ADSSN1, a strong off-target effect was observed in the treated group for knockdown dead end.

$\mathrm{F}_{1}$ ADSSN2 treatments yielded results as hypothesized. Nanos was significantly downregulated for $16.75 \mathrm{X}$ at $48 \mathrm{hpf}$ and $40.31 \mathrm{X}$ at $120 \mathrm{hpf}$ (Figure $3 \mathrm{~b}$ ), in untreated group. Most time points from the treated group had similar expression patterns as the non-transgenic control, except the off-target dead end at $48 \mathrm{hpf}$, which was significantly upregulated for 11.87X.

Both ADSScDNA treated and untreated $\mathrm{P}_{1}$ strongly upregulated the expression of nanos gene at three time points (Figure 4a). In the treated group, upregulation of nanos varied from 167.78X to $747.39 \mathrm{X}$ at the three time points, and the peak value was at $48 \mathrm{hpf}$. In the untreated group, the upregulation of nanos was from 32.51X (24 hpf) to 296.27X (120 hpf). Dead end was down regulated in both treated and untreated groups from $2 \mathrm{X}$ to $10 \mathrm{X}$ at three time points. Vasa and dead end was downregulated $8.17 \mathrm{X}$ and $10.01 \mathrm{X}$ at $120 \mathrm{hpf}$ in the treated group.

For the $\mathrm{F}_{1}$ generation, ADSScDNA downregulated nanos at three time points in the untreated groups (Figure $4 \mathrm{~b})$, especially at $48 \mathrm{hpf}(9.53 \mathrm{X})$. Fish with this construct were consistently downregulated for vasa. At $24 \mathrm{hpf}$, nanos, vasa and dead end were downregulated in a similar fashion in both treated and untreated groups.

For $\mathrm{P}_{1}$ ADSSDND exposed channel catfish, dead end was downregulated from 2.98X to 5.04X, at three time points in treated groups, and at $24 \mathrm{hpf}$ and $48 \mathrm{hpf}$ in untreated group (Figure 5a). At $120 \mathrm{hpf}$, dead end was significantly up regulated in the untreated group. Strong off-target effects 
were observed: vasa expression was knocked down at 48 and $120 \mathrm{hpf}$ in the untreated group, from $3.02 \mathrm{X}$ to $7.46 \mathrm{X}$.

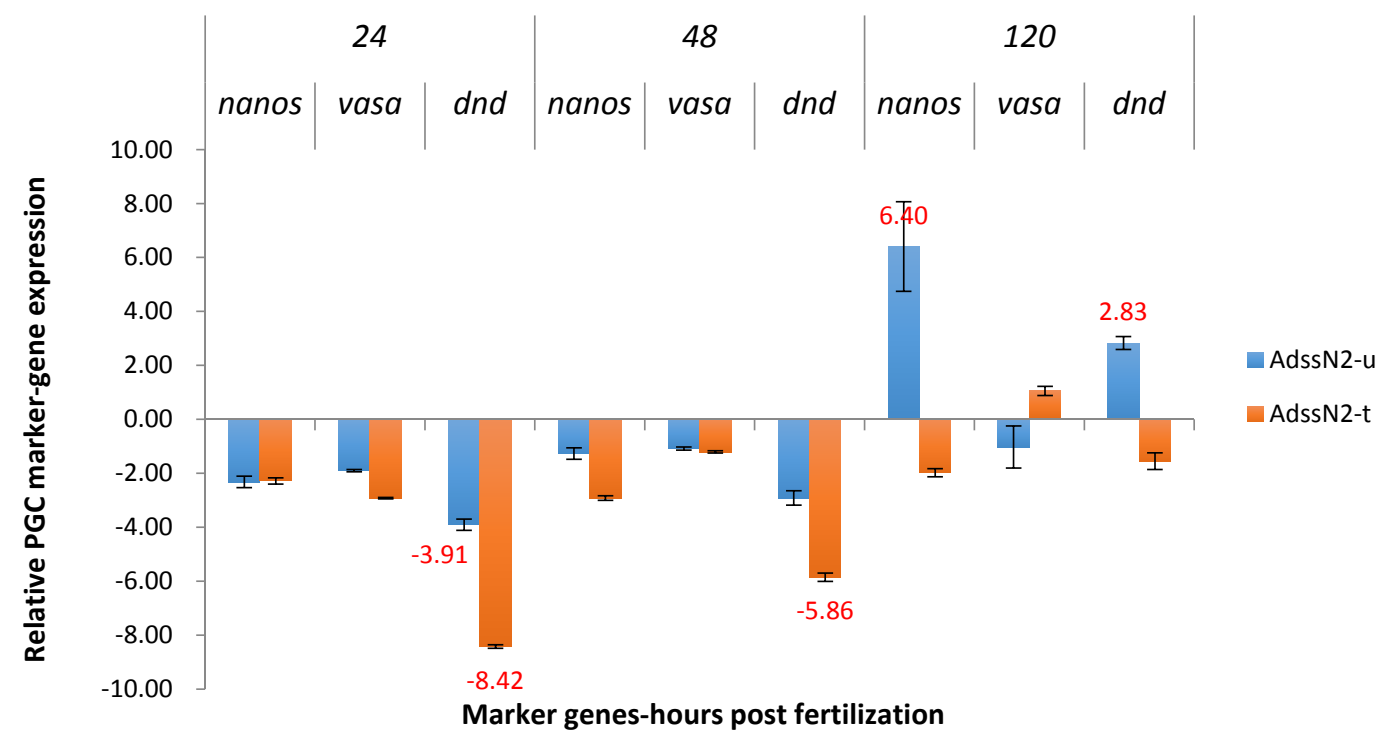

(a)

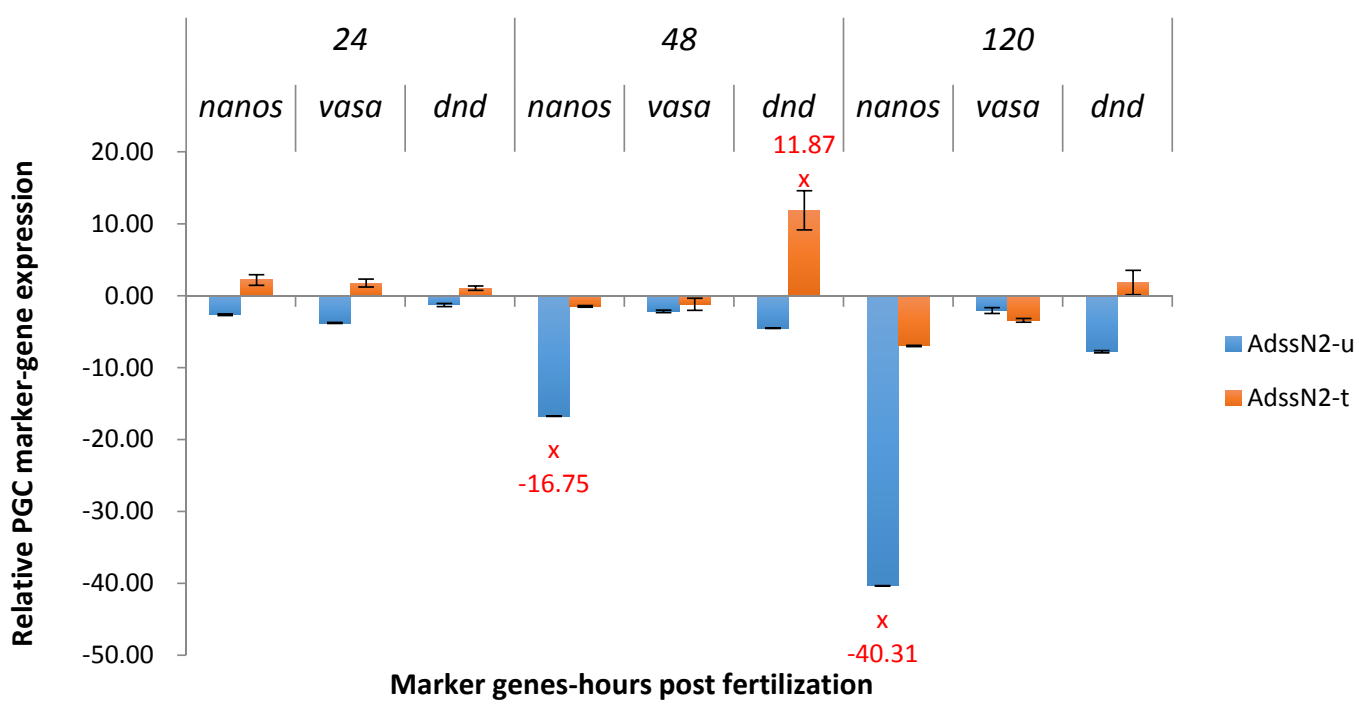

(b)

Figure 3. Relative expression of primordial germ cell (PGC) marker genes, nanos, vasa, and dead end $(d n d)$ in the treated and untreated groups exposed to zebrafish adenylosuccinate synthase 2 (adss2) gene (ADSS) promoter fused with $3^{\prime}$ end shRNAi targeting channel catfish nanos gene (N2) as $\mathrm{P}_{1}(\mathbf{a})$ and $\mathrm{F}_{1}$ (b) ADSSN2 transgenic channel catfish (Ictalurus punctatus) embryos. $u$ represents untreated group, $t$ represents treated group. The treated group was incubated in $4 \mathrm{ppt}$ sodium chloride. The samples were analyzed at 24,48 and $120 \mathrm{~h}$ post fertilization (hpf), respectively. Relative nanos, vasa, and dead end (dnd) gene expression was expressed as fold change over non-transgenic control samples at the same time point. All the red fold values numbers shown were significantly different compared to non-transgenic control at the level of $p<0.05$ using Pairwise Fixed Reallocation Randomization Test (PFRR) from REST (Relative Expression Software Tool). Red X on the SE bar indicated the relative expression between the treated and untreated groups was significantly different from each other using PFRR. 

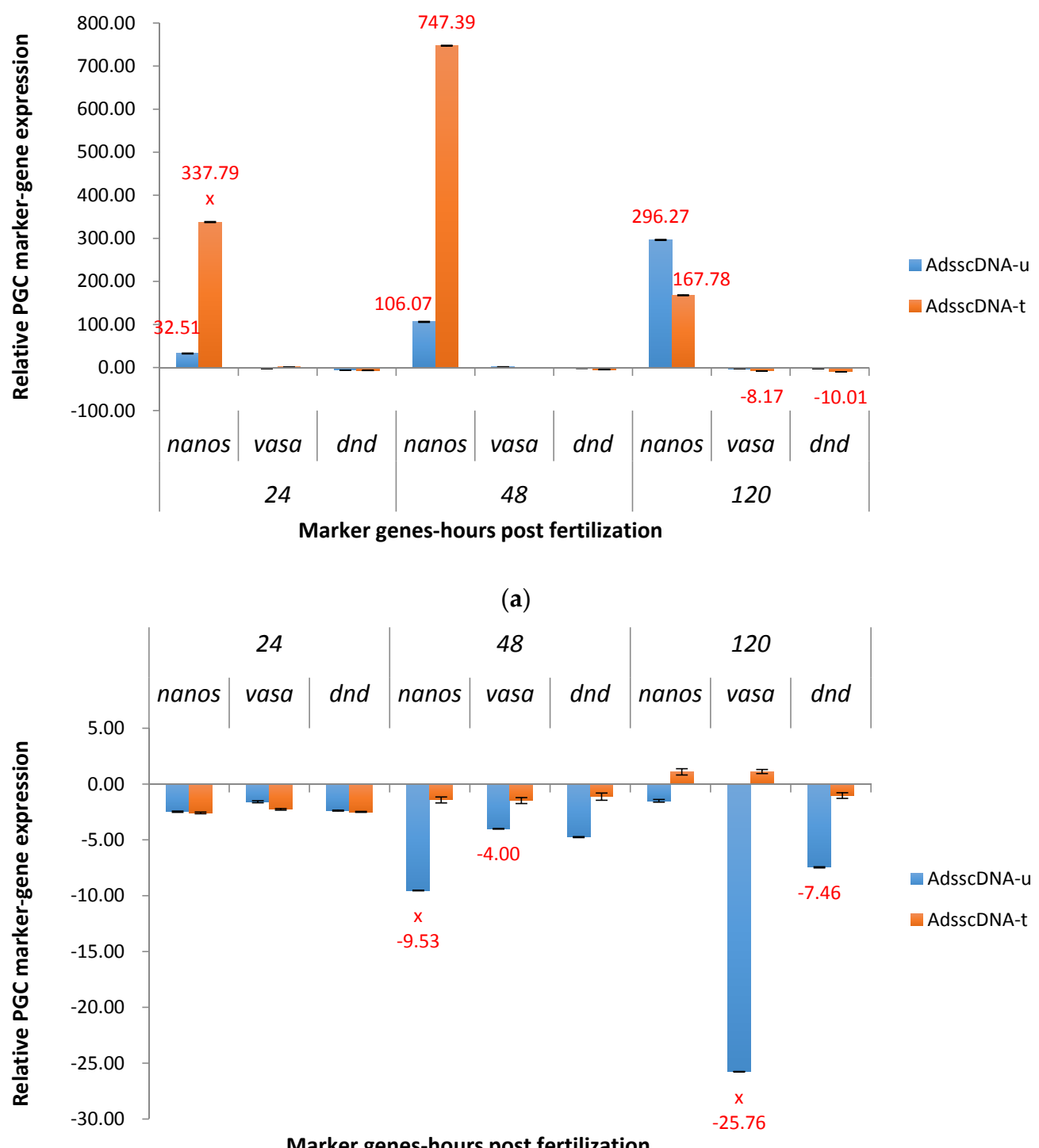

(b)

Figure 4. Relative expression of primordial germ cell (PGC) marker genes, nanos, vasa, and dead end $(d n d)$ in the treated and untreated groups exposed to zebrafish adenylosuccinate synthase 2 (adss2) gene (ADSS) promoter fused with full-length cDNA of channel catfish nanos gene (cDNA) as $\mathrm{P}_{1}$ (a) and $\mathrm{F}_{1}$ (b) ADSScDNA transgenic channel catfish (Ictalurus punctatus) embryos. $u$ represents untreated group, $t$ represents treated group. The treated group was incubated in $4 \mathrm{ppt}$ sodium chloride. The samples were analyzed at 24, 48 and $120 \mathrm{~h}$ post fertilization (hpf), respectively. Relative nanos, vasa, and dead end ( $(n d)$ gene expression was expressed as fold change over non-transgenic control samples at the same time point. All the red fold values numbers shown were significantly different compared to the non-transgenic control at the level of $p<0.05$ using Pairwise Fixed Reallocation Randomization Test (PFRR) from REST (Relative Expression Software Tool). Red X on the SE bar indicated the relative expression between the treated and untreated groups was significantly different from each other using PFRR.

The untreated $\mathrm{F}_{1}$ ADSSDND group was significantly downregulated for dead end at $48 \mathrm{hpf}(13.36 \mathrm{X})$ and $120 \mathrm{hpf}(18.63 \mathrm{X})$ (Figure 5b). Significant off-target downregulation was observed for nanos and vasa in the untreated group at all three time points, especially at $24 \mathrm{hpf}(8.61 \mathrm{X}$ for nanos and 9.53X for vasa), $48 \mathrm{hpf}$ (9.82X for vasa), and $120 \mathrm{hpf}$ (11.28X for nanos). 


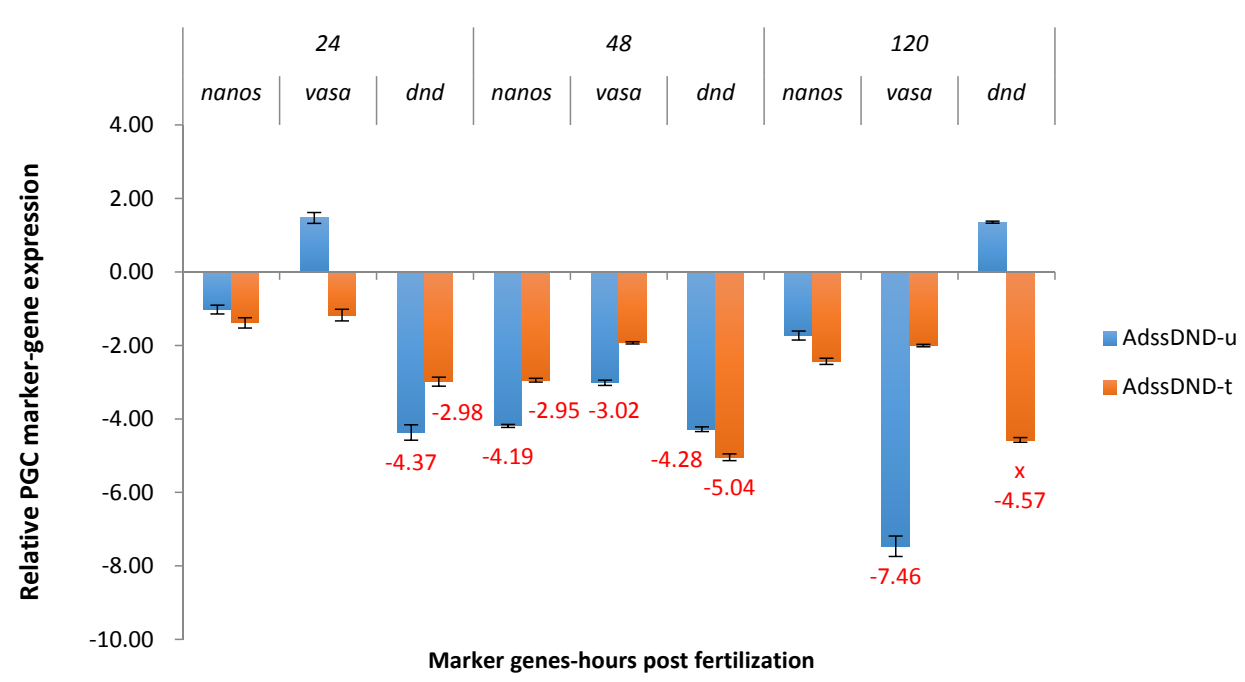

(a)

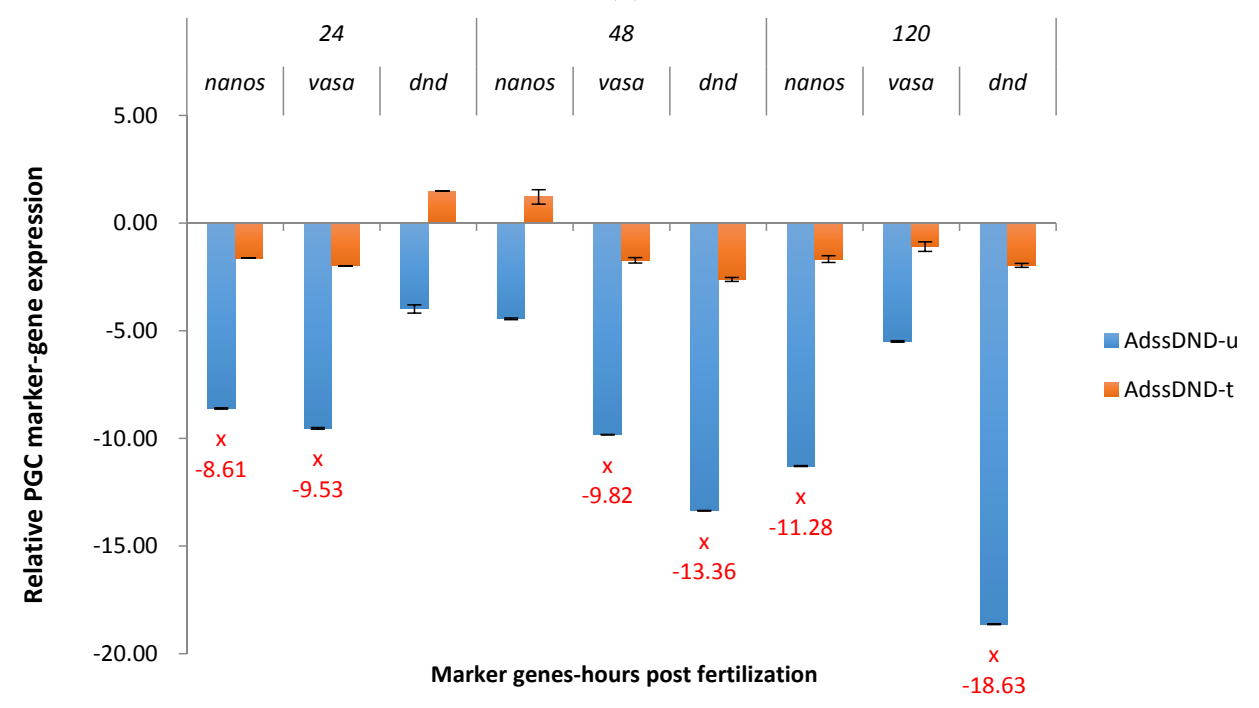

(b)

Figure 5. Relative expression of primordial germ cell (PGC) marker genes, nanos, vasa, and dead end $(d n d)$ in the treated and untreated groups exposed to zebrafish adenylosuccinate synthase 2 (adss2) gene (ADSS) promoter fused with shRNAi targeting channel catfish dead end gene (DND) as $\mathrm{P}_{1}(\mathbf{a})$ and $\mathrm{F}_{1}(\mathbf{b})$ ADSSDND transgenic channel catfish (Ictalurus punctatus) embryos. $u$ represents the untreated group, $t$ represents treated group. The treated group was incubated in $4 \mathrm{ppt}$ sodium chloride. The samples were analyzed at 24,48 and $120 \mathrm{~h}$ post fertilization (hpf), respectively. Relative nanos, vasa, and dead end ( $d n d)$ gene expression was expressed as fold change over non-transgenic control samples at the same time point. All the red fold values numbers shown were significantly different compared to the non-transgenic control at the level of $p<0.05$ using Pairwise Fixed Reallocation Randomization Test (PFRR) from REST (Relative Expression Software Tool). Red X on the SE bar indicated the relative expression between the treated and untreated groups was significantly different from each other using PFRR.

\subsubsection{RM System}

Nanos was slightly downregulated in $\mathrm{P}_{1}$ embryos electroporated with RMN1 construct at $24 \mathrm{hpf}$ and $48 \mathrm{hpf}$ in both treated and untreated groups (Figure 6a). At $120 \mathrm{hpf}$, nanos was upregulated in treated and untreated groups, 3.68X and 2.58X, respectively. The off-target dead end was downregulated at three time points in both groups, from $2.11 \mathrm{X}$ to $6.22 \mathrm{X}$. 


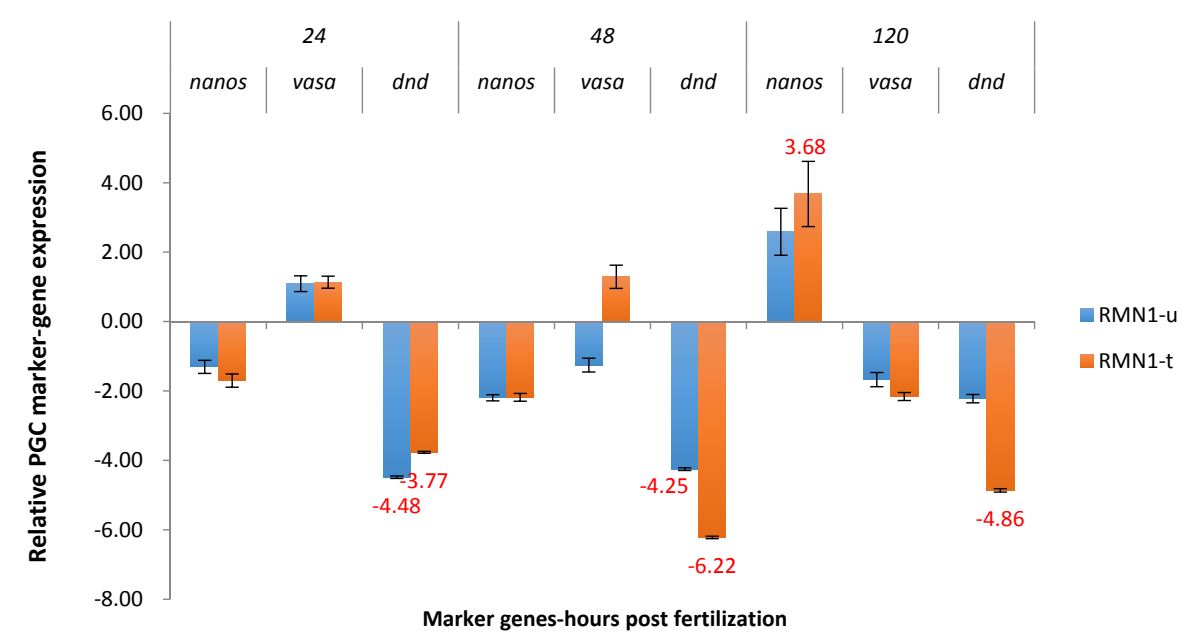

(a)

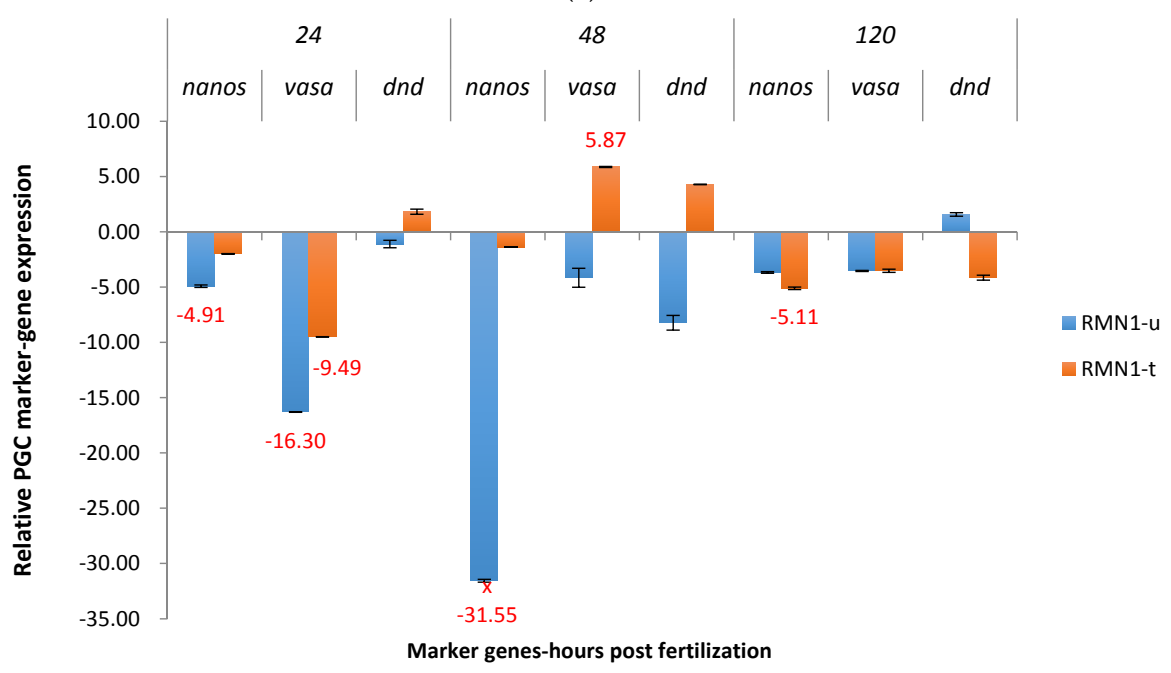

(b)

Figure 6. Relative expression of primordial germ cell (PGC) marker genes, nanos, vasa, and dead end $(d n d)$ in the treated and untreated groups exposed to zebrafish racemase gene (RM) promoter fused with $5^{\prime}$ end shRNAi targeting channel catfish nanos gene (N1) as $P_{1}(\mathbf{a})$ and $F_{1}$ (b) RMN1 transgenic channel catfish (Ictalurus punctatus) embryos. $u$ represents untreated group, $t$ represents treated group. The treated group was incubated in 4 ppt sodium chloride. The samples were analyzed at 24,48 and $120 \mathrm{~h}$ post fertilization (hpf), respectively. Relative nanos, vasa, and dead end (dnd) gene expression was expressed as fold change over non-transgenic control samples at the same time point. All the red fold values numbers shown were significantly different compared to the non-transgenic control at the level of $p<0.05$ using Pairwise Fixed Reallocation Randomization Test (PFRR) from REST (Relative Expression Software Tool). Red X on the SE bar indicated the relative expression between the treated and untreated groups was significantly different from each other using PFRR.

In untreated $\mathrm{F}_{1}$ RMN1 channel catfish embryos, nanos was downregulated from 3.54X to $31.55 \mathrm{X}$ at three points, while in the treated group, the expression of nanos was similar to the non-transgenic control, except at $120 \mathrm{hpf}$ (Figure 6b). In addition, off-target downregulation occurred for vasa at $24 \mathrm{hpf}$ (16.30X) in the untreated group and 9.49X in the treated group.

At $24 \mathrm{hpf}$ and $48 \mathrm{hpf}$, untreated $\mathrm{P}_{1}$ embryos exposed to RMN2 were downregulated for nanos, 2.32X and 2.07X (Figure 7a). The salt treatment repressed downregulation of nanos at 24 and $48 \mathrm{hpf}$, but not at $120 \mathrm{hpf}$ (2.10X). Off-target downregulation, 1.85X to 5.39X, was observed for dead end in both groups at three time points. The differences in expression between salt treated and untreated embryos 
at the same time point were minimal. At $48 \mathrm{hpf}$, vasa was also significantly downregulated, 3.19X, in the untreated group.

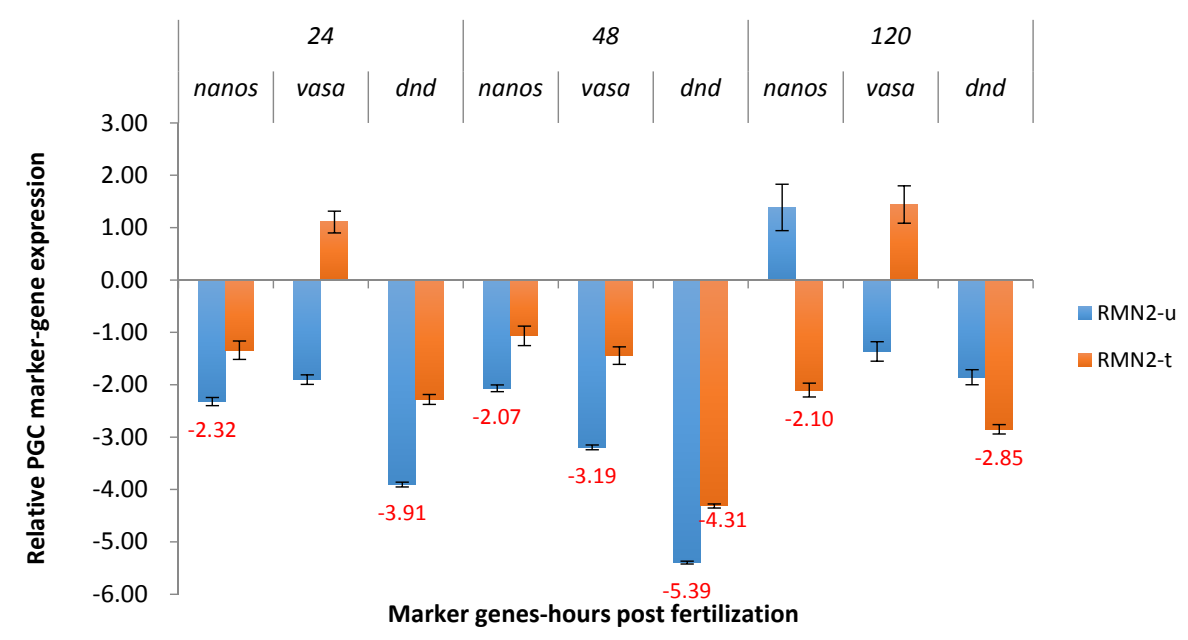

(a)

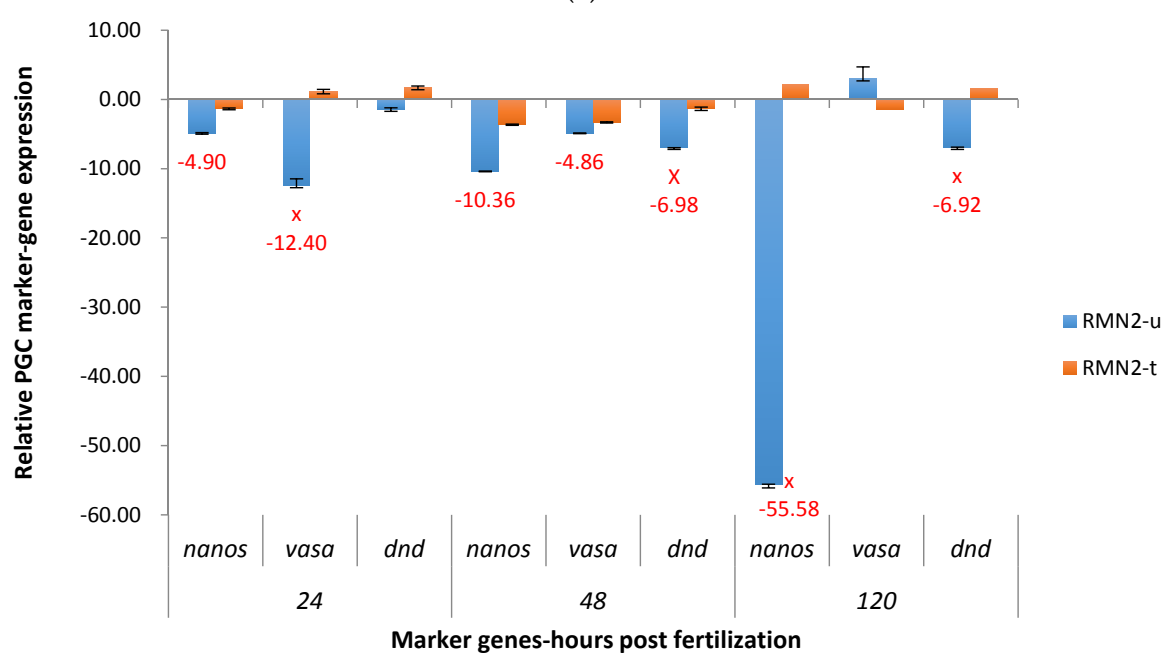

(b)

Figure 7. Relative expression of primordial germ cell (PGC) marker genes, nanos, vasa, and dead end $(d n d)$ in the treated and untreated groups exposed to zebrafish racemase gene (RM) promoter fused with $3^{\prime}$ end shRNAi targeting channel catfish nanos gene (N2) as $\mathrm{P}_{1}$ (a) and $\mathrm{F}_{1}$ (b) RMN2 transgenic channel catfish (Ictalurus punctatus) embryos. $u$ represents untreated group, $t$ represents treated group. The treated group was incubated in $4 \mathrm{ppt}$ sodium chloride. The samples were analyzed at 24,48 and $120 \mathrm{~h}$ post fertilization (hpf), respectively. Relative nanos, vasa, and dead end (dnd) gene expression was expressed as fold change over non-transgenic control samples at the same time point. All the red fold values numbers shown were significantly different compared to the non-transgenic control at the level of $p<0.05$ using Pairwise Fixed Reallocation Randomization Test (PFRR) from REST (Relative Expression Software Tool). Red X on the SE bar indicated the relative expression between the treated and untreated groups was significantly different from each other using PFRR.

In the case of $F_{1}$ RMN2 channel catfish embryos, nanos was significantly downregulated at three time points in the untreated group (4.90X to 55.58X) (Figure 7b). For salt treated groups, downregulation of nanos was successfully repressed. Off-target effects occurred as vasa and dead end also had decreased expression, at $24 \mathrm{hpf}$ and $48 \mathrm{hpf}$ for vasa, $48 \mathrm{hpf}$ and $120 \mathrm{hpf}$ for dead end in the untreated group. 
Upregulation of nanos in $\mathrm{P}_{1}$ RMcDNA electroporated embryos was significant, 29.44X (120 hpf) to $510.83 \mathrm{X}$ (48 hpf) in both groups (Figure 8a). In the untreated group, the upregulation of nanos was continuously increasing from $32.51 \mathrm{X}(24 \mathrm{hpf})$ to $384.38 \mathrm{X}(120 \mathrm{hpf})$, and in the treated group, the upregulation started at $275.90 \mathrm{X}$ at $24 \mathrm{hpf}$, reached its peak of $510.83 \mathrm{X}$ at $48 \mathrm{hpf}$, and then decreased to 29.44X at $120 \mathrm{hpf}$.

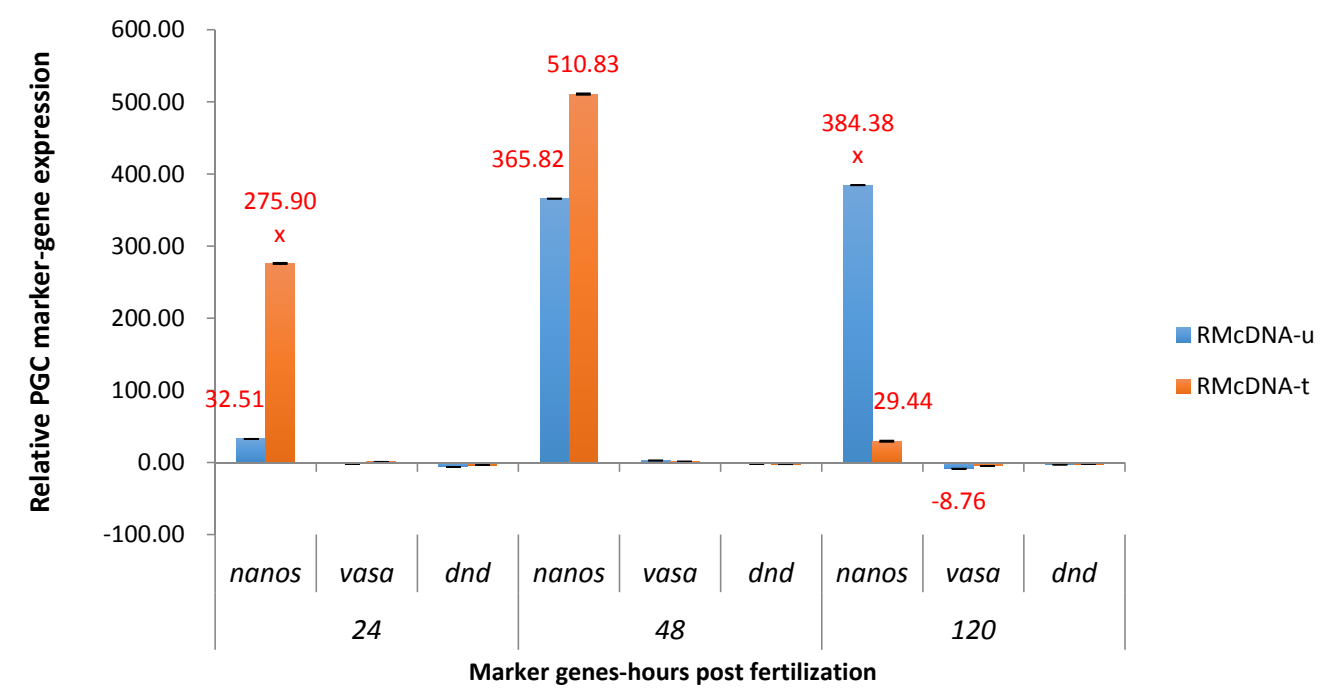

(a)

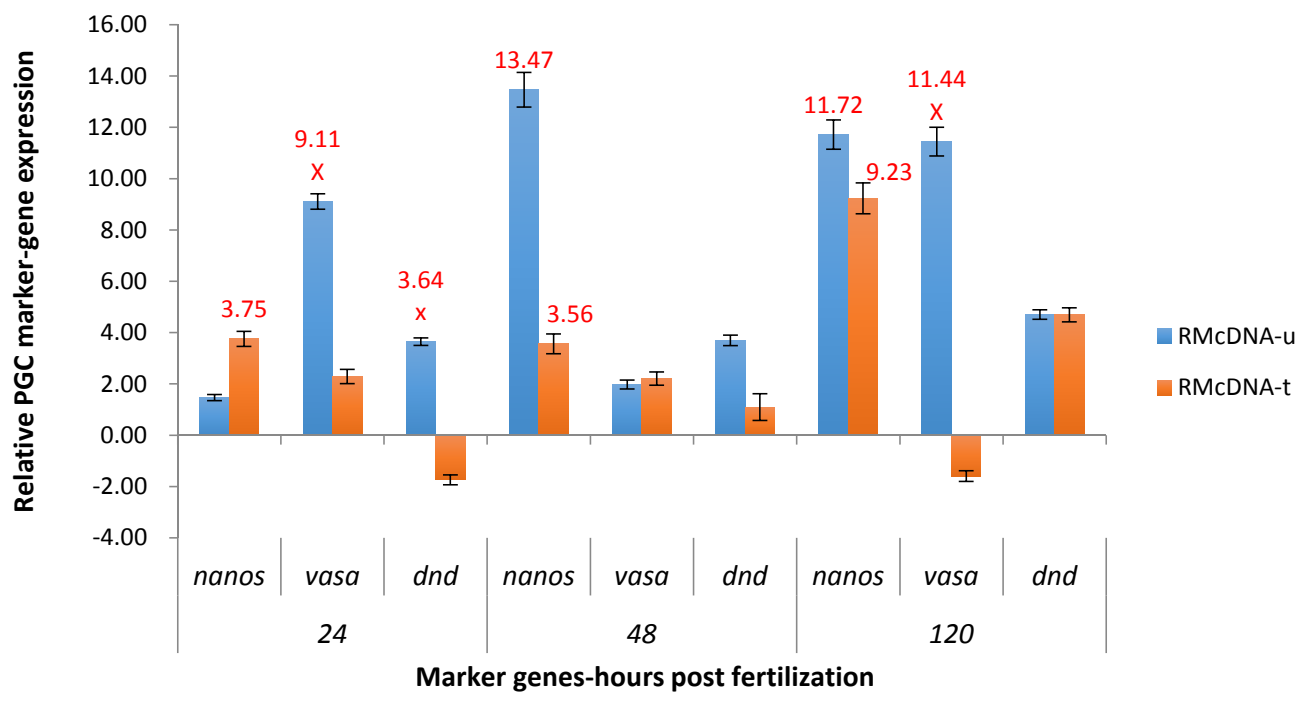

(b)

Figure 8. Relative expression of primordial germ cell (PGC) marker genes, nanos, vasa, and dead end $(d n d)$ in the treated and untreated groups exposed to zebrafish racemase gene (ADSS) promoter fused with full-length cDNA of channel catfish nanos gene (cDNA) as $\mathrm{P}_{1}(\mathbf{a})$ and $\mathrm{F}_{1}(\mathbf{b})$ RMcDNA transgenic channel catfish (Ictalurus punctatus) embryos. $u$ represents untreated group, $t$ represents treated group. The treated group was incubated in $4 \mathrm{ppt}$ sodium chloride. The samples were analyzed at 24, 48 and $120 \mathrm{~h}$ post fertilization (hpf), respectively. Relative nanos, vasa, and dead end (dnd) gene expression was expressed as fold change over non-transgenic control samples at the same time point. All the red fold values numbers shown were significantly different compared to the non-transgenic control at the level of $p<0.05$ using Pairwise Fixed Reallocation Randomization Test (PFRR) from REST (Relative Expression Software Tool). Red X on the SE bar indicated the relative expression between the treated and untreated groups was significantly different from each other using PFRR. 
For $\mathrm{F}_{1}$ embryos in the untreated RMcDNA group, nanos was significantly upregulated at $48 \mathrm{hpf}$ and $120 \mathrm{hpf}, 13.47 \mathrm{X}$ and 11.72X, respectively (Figure $8 \mathrm{~b}$ ). In the salt treated group, the upregulation of nanos was largely repressed compared to untreated at $48 \mathrm{hpf}$ (downregulation of 3.56X), but not at $120 \mathrm{hpf}$ (9.23X). Strong off-target effects for vasa were apparent at $24 \mathrm{hpf}$ (upregulation of 9.11X) and $120 \mathrm{hpf}$ (upregulation of 11.44X) for the untreated group.

Dead end was downregulated, 1.71X to 3.42X, for RMDND in both $\mathrm{P}_{1}$ groups at three time points except in treated group at $24 \mathrm{hpf}$ (upregulated 164.19X) (Figure 9a). Additionally, vasa and nanos were significantly knocked down at $120 \mathrm{hpf}$ in the untreated group (4.98X and 4.37X).
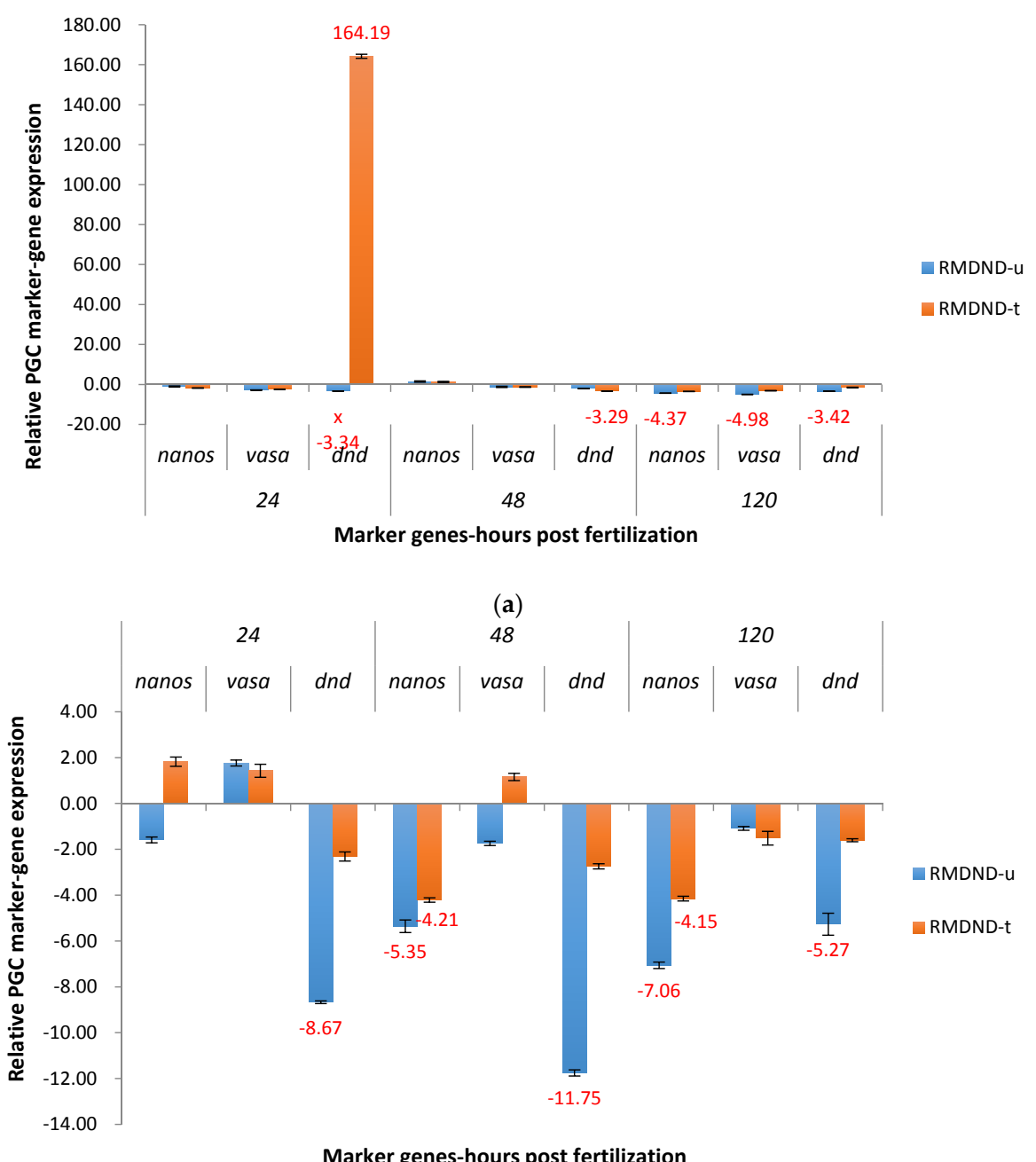

(b)

Figure 9. Relative expression of primordial germ cell (PGC) marker genes, nanos, vasa, and dead end $(d n d)$ in the treated and untreated groups exposed to zebrafish racemase gene (RM) promoter fused with shRNAi targeting channel catfish dead end gene (DND) as $\mathrm{P}_{1}(\mathbf{a})$ and $\mathrm{F}_{1}(\mathbf{b})$ RMDND transgenic channel catfish (Ictalurus punctatus) embryos. $u$ represents untreated group, $t$ represents treated group. The treated group was incubated in 4 ppt sodium chloride. The samples were analyzed at 24,48 and $120 \mathrm{~h}$ post fertilization (hpf), respectively. Relative nanos, vasa, and dead end (dnd) gene expression was expressed as fold change over non-transgenic control samples at the same time point. All the red fold values numbers shown were significantly different compared to the non-transgenic control at the level of $p<0.05$ using Pairwise Fixed Reallocation Randomization Test (PFRR) from REST (Relative Expression Software Tool). Red X on the SE bar indicated the relative expression between the treated and untreated groups was significantly different from each other using PFRR. 
The target gene dead end was significantly downregulated, 5.27X to 11.75X, in the $\mathrm{F}_{1}$ untreated RMDND group at three time points (Figure 9b). In the treated group, downregulation of dead end was rapidly reduced at each time point compared to the untreated group to a level of $-1.60 \mathrm{X}$ to $-2.74 \mathrm{X}$. Nanos was significantly downregulated in both groups at $48 \mathrm{hpf}$ and $120 \mathrm{hpf}$, indicative of a strong off-target effect or gene interaction.

\section{Discussion}

Knockdown constructs using shRNAi and overexpression of cDNA that targeted the PGC genes, nanos and dead end, which play important roles in PGC migration, were electroporated into channel catfish to achieve transgenic sterilization. Subsequently, $\mathrm{F}_{1}$ individuals were produced containing the knockdown constructs. These constructs were designed to be repressed by application of salt to accomplish repressible transgenic sterilization. Gene expression of PGC marker genes during the early development of $\mathrm{P}_{1}$ electroporated individuals, thus exposed to the constructs during putative PGC migration, that were either treated with $4 \mathrm{ppt}$ sodium chloride or untreated indicated that, in some cases, the constructs were able to downregulate the targets or overexpress the target genes, but the repression was not very effective or in some cases, actually enhanced down or upregulation. The results were different for $F_{1}$ transgenic individuals, as sterilization constructs were downregulating the key PGC genes, and that the repression was generally successful. However, the cDNA overexpression constructs did not work as expected with the ADSS driven construct reducing mRNA levels, but the RM driven construct dramatically increasing the mRNA levels. Many complementary off-target effects on the related PGC genes were observed. Spawning data on $P_{1}$ treated and untreated brood stock exposed to the transgenes as embryos supported the hypothesis that the repressible transgenic system based on sodium chloride sensitive promoters is workable as spawning rates of the sodium chloride treated fish was higher than the untreated.

In the case of control channel catfish embryos that had not been exposed to the transgenes, levels of nanos mRNA dropped naturally from 24 to $120 \mathrm{hpf}$, dead end dropped slightly faster than nanos, and vasa was dramatically lower, at $120 \mathrm{hpf}$ compared to $24 \mathrm{hpf}$. Either the expression of mRNA of those three PGC migration marker genes was downregulated naturally or there was maternally derived mRNA of those marker genes in the early phase of embryonic development, which was being degraded later in embryogenesis. However, maternally derived nanos mRNA in zebrafish degrades rapidly before gastrulation [6], and Xu et al. [31] have shown that during embryogenesis in Asian seabass (Lates calcarifer), the vasa transcript is abundant in early stages, and persists at a reduced and detectable level in late stages. This supports the premise that the decreases in the nanos, vasa, and dead end mRNA levels in channel catfish were due to natural and transgenic downregulation, and not just degradation.

These observations on embryonic expression levels of nanos, vasa, and dead end mRNA might have implications for different knockdown strategies to prevent migration of PGCs and their potential success in channel catfish and other fish species [32]. Understanding the mRNA regulation pattern of the target genes would help us better explain the knockdown results at different time points. A more detailed study of the expression level of these three mRNAs in embryonic development of channel catfish might be beneficial for identifying the transgenic sterilization constructs with the best probability of success and further refinement of the repressible transgenic sterilization systems.

Previous data using copper sensitive promoters in zebrafish and channel catfish for repressible sterilization on $\mathrm{P}_{1}$ embryos have shown that they were able to drive transcription in channel catfish and common carp embryos that had been electroporated with the knockdown constructs and likely had large copy numbers in their cytoplasm [32,33]. The expression data of copper systems on the PGC targets of the $F_{1}$ transgenic embryos that had integrated copies of the repressible transgenic sterilization constructs was in general agreement with the results from the $\mathrm{P}_{1}$ (unpublished data). The salt and copper systems both show good potential for repressible transgenic sterilization, and both present viable options for further development of this concept. 
The knockdown/overexpression and repression efficiency were quite different between $\mathrm{P}_{1}$ and $F_{1}$ samples. Based on previous unpublished research from our laboratory, we predicted that the embryonic exposure to the constructs in the $P_{1}$ generation would be indicative of results in the $F_{1}$, but they did not correlate well. The $\mathrm{P}_{1}$ expression data did show that the constructs were capable of downregulation, but the repression appeared problematic. The downregulation in the $\mathrm{F}_{1}$ transgenic embryos was often greater than their parental embryos that were exposed to the foreign constructs via electroporation, and the repression often more efficient in $\mathrm{F}_{1}$ embryos. Another difference between $\mathrm{P}_{1}$ and $F_{1}$ generations was that in ADSScDNA and RMcDNA, nanos was dramatically upregulated in the parental generation, but the upregulation was repressed or reversed in $\mathrm{F}_{1}$.

There are several potential explanations for the differing results observed between the $P_{1}$ and $\mathrm{F}_{1}$. $\mathrm{P}_{1}$ were likely a mixture of both transgenic and non-transgenic embryos as integration rates would likely between $30 \%$ and $70 \%$ [28]. We expect that exposure to the constructs should cause sterilization if they are expressing, however, the percentage of embryos for which the electroporation was successful and how many molecules penetrated the developing embryos is unknown. Expression of positive or exposed embryos could be partially masked by those that are negative or for those that the electroporation was not successful. These results also show that although data on $\mathrm{P}_{1}$ for embryonic traits generated from exposure to transgenes has some value and relationship to what might be obtained in integrated $F_{1}$ individuals, the relationship may not be perfectly predictive. Results for $P_{1}$ and $\mathrm{F}_{1}$ common carp exposed or containing a shRNAi targeting aromatase were contradictory [34]. However, in this case, usefulness of the $\mathrm{P}_{1}$ data may have been more compromised, as the trait in question, gender, is determined several days after hatching.

Strong off-target effects for related PGC genes were common in both $\mathrm{P}_{1}$ and $\mathrm{F}_{1}$ generations. The off-target effects might be caused by mismatch of siRNA [35,36]. In addition, there might be strong genetic interaction effects among nanos, vasa and dead end (Table 3). Dead end protein acting to counteract the inhibitory function of several miRNAs, thereby allowing the expression of PGC specific proteins such as nanos and $t d r d 7$ [18,37]. In Drosophila, the vasa gene encodes an ATP-dependent RNA helicase of the DEAD-box family and was required for promoting translation of at least two known mRNAs, nanos and gurken [38]. Dazl stimulates vasa translation by binding to the $3^{\prime}$ UTR of vasa mRNA in vivo, Dazl knockout mice have reduced levels of vasa protein [39]. In mouse, nanos2 post-transcriptionally represses Dazl mRNA expression in germ cells [40], therefore indirectly regulate the expression of vasa. In human, $d n d 1$ have strong interaction score with dazl by prediction [41]. Consistent with this observation, ADSSDND targeted dead end, but also downregulated nanos and vasa, at all three time points; knockdown of nanos in RMN2 also downregulate vasa and dead end at different time points. Although there was no evidence of nanos affecting the expression of dead end, it is possible there are undiscovered direct or indirect interactions between them. If the off-target effects were restricted to PGC migration loci, they may contribute to sterility.

In $F_{1}$ generation, knockdown and repression in most constructs were much closer to what was expected compared to the results from their parents. In untreated groups, the knockdown constructs were able to significantly downregulate the mRNA expression of the corresponding target gene. In treated groups, sodium chloride treatment repressed expression of knockdown constructs and the mRNA levels of the target genes were near normal. The following constructs, ADSSN2, ADSSDND, RMN2, RMDND, had the best patterns of downregulation with effective repression, followed by RMN1 (not at all timepoints) and ADSScDNA (strong off-target effects with repression). These results are even more encouraging, considering we usually obtain an inheritance rate of $20-50 \%$ for the F1 generation. Thus, one-half or less of the embryos in the pooled positive samples are likely transgenic. Significantly different expression levels, downregulation, were obtained even though there were non-transgenic individuals mixed in with the transgenic embryos.

In some cases, knockdown for the target gene was inconsistent at different embryonic stages evaluated. It is not known exactly when the critical period of PGC marker gene knockdown is that ensures the PGC does not reach the genital ridge or dies. Based on our results, it appears it is not 
necessary to knockdown the PGC gene expression during all of embryogenesis to achieve sterilization since in some cases knockdown was only achieved during one time period, yet $\mathrm{P}_{1}$ still had a reduced rate of reproduction. However, further research is necessary to confirm these apparent results, and to further refine the repressible sterilization system.

Table 3. Interaction between nanos, vasa and dead end. From the current experiment, assuming interaction rather than off-target knockdown, knockdown of dead end resulted in downregulation of nanos and vasa, knockdown of nanos resulted in downregulation of vasa and dead end. Dead end can regulate nanos by inhibiting the activity of miR-430 and protect nanos from degradation [18,37]. Dead end might be involved in regulation of $d a z l$, thus indirectly regulates the expression of vasa [39,41]. Vasa is required for promoting the translation of nanos [38]. Nanos regulates vasa by suppressing the expression of dazl $[39,40]$. The potential mechanism of nanos regulating the expression of dead end is still unknown.

\begin{tabular}{cccc}
\hline Regulator Gene & Nanos & Vasa & Dead End \\
\hline Nanos & $\begin{array}{c}\text { Vasa is required for } \\
\text { promoting } \\
\text { translation of nanos }\end{array}$ & $\begin{array}{c}\text { Dead end protects nanos } \\
\text { from being degraded by } \\
\text { miR-430 in germ cells }\end{array}$ \\
\hline Vasa & $\begin{array}{c}\text { Nanos suppresses dazl, dazl } \\
\text { regulates vasa expression }\end{array}$ & $\begin{array}{c}\text { Dead end potentially } \\
\text { regulates dazl, dazl } \\
\text { regulates vasa expression }\end{array}$ \\
\hline Dead end & $\begin{array}{c}\text { Nanos potentially regulates } \\
\text { dead end, mechanism unknown }\end{array}$ & $\begin{array}{c}\text { No known } \\
\text { regulation found }\end{array}$ & \\
\hline
\end{tabular}

With respect to spawning, ADSSN2 was the best system (treated $\mathrm{P}_{1}$ with higher spawning rate than untreated). In general, the repression was quite effective, as the treated brood stock had $93 \%$ spawning rate for all treatments pooled compared to $59 \%$ spawning rate for the untreated brood stock. To meet the goal of eliminating environmental risk and preventing introgression of the transgene into wild populations, the sterilization likely need to be $100 \%$ effective, and would likely be a requirement of regulatory agencies. Biologically, an effectiveness of less than $100 \%$ would likely still achieve the goal of the transgenes not establishing unless they had a selective advantage. This rate of sterilization in the $\mathrm{P}_{1}$ was not achieved, which was not surprising because of the expected mosaicism in $\mathrm{P}_{1}$ transgenic fish and the fact that electroporation may not have been successful for each embryo. The observed spawning differences between the treated and untreated $\mathrm{P}_{1}$ brood stock indicate that this salt-based sterilization and repression system has good potential. $\mathrm{F}_{1}$ spawning data will be needed to determine if this system can be $100 \%$ effective. Based upon preliminary, unpublished results with related constructs, we predict $100 \%$ sterility of the $\mathrm{F}_{1}$ with the salt-sensitive constructs.

Four ppt sodium chloride was used as the repressor. Future research is needed regarding the minimum doses needed to repress the knockdown constructs. This is especially important as if the promoters are too sensitive and can be repressed at low, but naturally found levels of sodium chloride, escaped transgenic channel catfish could establish in the wild, negating the usefulness of the sterilization constructs evaluated in the current study. Channel catfish and blue catfish, I. furcatus, have spawned on rare occasion at salinity levels as high as 2 ppt [42]. For the vast majority of the geographic range of channel catfish, the salinity is less than $100 \mathrm{ppm}$. Likely, ADSS and RM promoters need to not be sensitive to $2.5 \mathrm{ppt}$ sodium chloride and lower for this transgenic sterilization system to be commercially applicable. Otherwise, escaped catfish transgenic for performance traits stacked with the salt sterilization constructs could spawn if they encountered partially saline water in estuarine environments that repressed the construct. If these constructs were selectively advantageous, the transgenes could become established in the natural environment with possible positive, negative or neutral impacts on the ecosystem. If these promoters are repressed at $\leq 2.5 \mathrm{ppt}$, it might be possible to alter them to be less sensitive to salt to make them usable in the entire geographic range of channel catfish to prevent establishment of transgenic channel catfish. 


\section{Materials and Methods}

All investigations and experimental studies on animals were conducted according to Institutional Animal Care and Use Committees (IACUC) and Association for Assessment and Accreditation of Laboratory Animal Care (AAALAC) protocols and guidelines.

\subsection{Construction of Plasmids}

FRMwg plasmid [30] was used as the vector for all the transgene constructs in this experiment, and it had three functional components: insulator, ocean pout (Zoarces americanus) terminator and boundary element. Between these components, there were two salt sensitized promoters that activate the expression of knockdown constructs: a $577 \mathrm{bp}$ zebrafish adss2 (ADSS) promoter and a $565 \mathrm{bp}$ zebrafish racemase (RM) promoter.

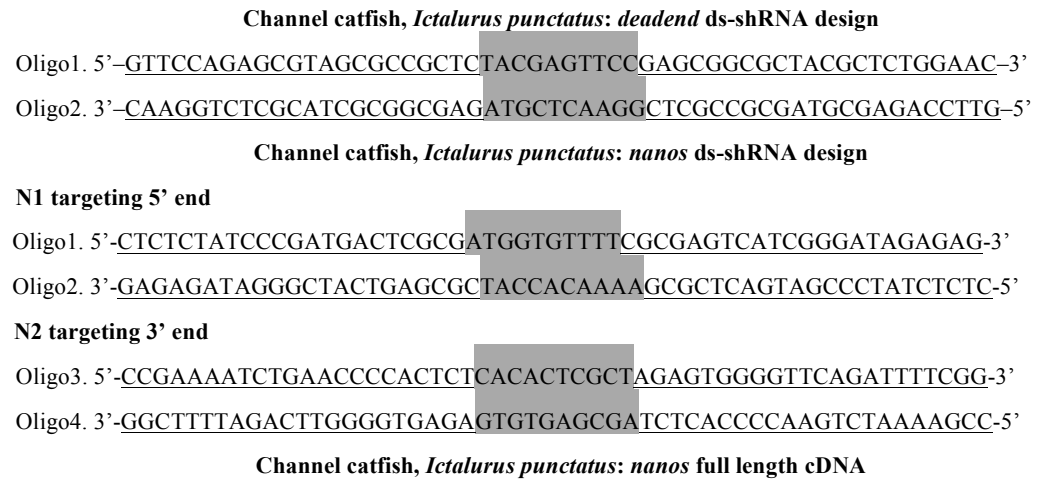

Figure 10. Primordial germ cell knockdown sequences for channel catfish, Ictalurus punctatus. Loops were in grey shade, stem sequences are underlined. Channel catfish nanos full-length cDNA was sequenced by $\mathrm{Su}$ et al. [32]. 
Channel catfish full-length nanos cDNA and dead end sequences were known (GenBank: KM874264.1 and KM874265.1). Based on these sequences, three RNAi and one cDNA sequence were ligated into the knockdown constructs targeting the marker genes (Figure 10). The knockdown strategies included: (1) a ds-sh RNA targeting the $5^{\prime}$ end of channel catfish nanos gene (N1); (2) a ds-sh RNA targeting the $3^{\prime}$ end of channel catfish nanos gene (N2); (3) a full length cDNA sequence of channel catfish nanos gene to overexpress nanos (cDNA); and (4) a ds-sh RNA targeting channel catfish dead end gene (DND). Except for the nanos cDNA sequence, all other constructs have a short hairpin structures and double stranded RNAs.

These constructs were designed and built as Tet-off-like systems (Figure 11). The constructs were synthesized at Genscript Biotech Corporation (Piscataway, NJ, USA).

a

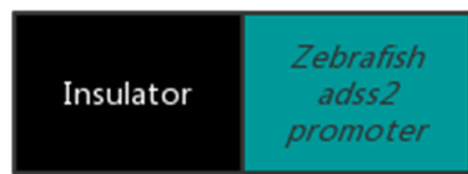

Knockdown constructs
Ocean pout

terminator
Boundary

element

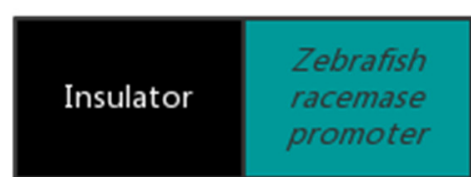

Knockdown constructs

\section{Ocean pout \\ terminator}

Boundary element

Figure 11. Primordial germ cell knockdown constructs for the sterilization of channel catfish, Ictalurus punctatus. (a) ADSS: The zebrafish adenylosuccinate synthase 2 promoter is salt sensitive and was repressed by sodium chloride higher at 4 ppt. (b) RM: The zebrafish racemase promoter is salt sensitive and was repressed by sodium chloride higher at 4 ppt. Insulator, ocean pout terminator and boundary element were from FRMwg plasmid (GenBank: AF170915.1).

\section{2. $P_{1}$ Fish}

Plasmids with the transgene of interest were cloned into Invitrogen Top 10 E. coli cells, according to the recommended protocols by Invitrogen (user guide 280126, Invitrogen, Carlsbad, CA, USA). After the appropriate period of cloning cell culture, plasmid DNA was extracted using the Qiagen maxi-prep kit (Cat No./ID: 12163) and linearized with SfiI (20,000 units/mL, BioLabs, Ipswich, MA, USA). Plasmids were then purified using the phenol-chloroform-ethanol method and quantified using Thermo scientific Nanodrop2000 ${ }^{\circledR}$ (Thermo Fisher Scientific, Waltham, MA, USA). Transgenes were transferred into one-cell, fertilized eggs using electroporation with a Baekon 2000 macromolecule transfer system (Baekon, Inc., Saratoga, CA, USA) to generate the $\mathrm{P}_{1}$ brood stock in the current experiment. Electroporation parameters were set at $6 \mathrm{kV}, 2^{7}$ pulses, $0.8 \mathrm{~s}$ burst, 4 cycles, $160 \mu \mathrm{s}[28,32]$. Non-contact mode of electroporation with the electrode 1-2 $\mathrm{mm}$ above the buffer was applied. This procedure generated the $\mathrm{P}_{1}$ brood stock used in the current experiment.

\subsection{Artificial Spawning and Embryo Culture}

During catfish spawning seasons when water temperature was $25^{\circ} \mathrm{C}$ or higher, gravid females and well developed males were injected or implanted with luteinizing hormone releasing hormone analogue (LHRHa) to induce the ovulation of eggs and sperm with a priming dose of $30 \mu \mathrm{g} \cdot \mathrm{kg}^{-1}$ followed by a resolving dose of $150 \mu \mathrm{g} \cdot \mathrm{kg}^{-1}$ dose $12 \mathrm{~h}$ later [43,44]. When females began to ovulate they were anesthetized in $200 \mathrm{mg} \cdot \mathrm{L}^{-1}$ tricaine methanesulfonate (Finquel: MS-222) with equal parts of $\mathrm{NaHCO}_{3}$ to maintain neutral $\mathrm{pH}$ for $10 \mathrm{~min}$ and then rinsed with freshwater [45]. Eggs were then hand stripped into a metal pan greased with vegetable shortening.

$\mathrm{P}_{1}$ males and females putatively transgenic with the same transgene constructs were used to produce $F_{1}$ offspring. Since $P_{1}$ transgenic fish are always mosaic and usually mosaic by tissue [28], 
"transgenic" brood stock were identified based on the presence of the transgene in their $\mathrm{F}_{1}$ progeny. Thus, the initial incubation and treatments for the $F_{1}$ were blind in regards to transgenic and non-transgenic groups. Testes were collected from euthanized males with well-developed secondary characteristics. Sperm were collected and then diluted with $0.9 \%$ saline at a 1:9 sperm: saline ratio.

For fertilization, 2-3 mL diluted sperm solution was added to about 300 eggs then mixed. Enough pond water to submerse the eggs was added for gamete activation and fertilization. After $5 \mathrm{~min}$, the pans with embryos were transferred to a trough with flow-through water and calcium for $1 \mathrm{~h}$ for water hardening. Embryos for treated groups $(T)$ were then transferred into aerated tubs with $5 \mathrm{~L}$ modified Holtfreter's solution $\left(\mathrm{NaCl} 4 \mathrm{~g}, \mathrm{NaHCO}_{3} 0.2 \mathrm{~g}, \mathrm{KCl} 0.05 \mathrm{~g}, \mathrm{MgSO}_{4} 333 \mu \mathrm{L}(300 \mathrm{~g}\right.$ in $500 \mathrm{~mL}$ ), $\mathrm{CaCl}_{2} 333 \mu \mathrm{L}$ (150 g in $500 \mathrm{~mL}$ ), pH: 7-7.5 in 1.0 L Dechlorinated water) [46]. Embryos from untreated groups $(U)$ were transferred into flow through troughs fitted with aeration and paddlewheels for incubation.

The repressor treatment was 4 ppt sodium chloride, and, in this case, incubation was in tubs holding approximately 100 embryos and the treatment was continuous for the first 6 days of embryonic development. Incubation solutions were changed every $24 \mathrm{~h}$.

\subsection{Embryo Sample Collection and RNA Extraction}

Triplicate samples of embryos were collected at 24,48 and $120 \mathrm{~h}$ post-fertilization (hpf) for both $\mathrm{T}$ and $\mathrm{U}$ groups. A total of 10-15 embryos were collected per replicate, paper towel dried, placed into $1.5 \mathrm{~mL}$ Eppendorf tube and immediately frozen in liquid nitrogen. Samples were then stored in $-80^{\circ} \mathrm{C}$ for future RNA or DNA extraction. Non-transgenic samples were also collected as a control.

Samples were ground into powder and dissolved in Invitrogen TRIzol ${ }^{\circledR}$ reagent (catalog \# 15596-018), and RNA was then extracted following the manufacturer's instructions. The quality and concentration of all the RNA samples were checked by both gel electrophoresis and with a Thermo scientific Nanodrop2000 ${ }^{\circledR}$. All extracted samples had an $\mathrm{A}_{260 / 280}$ ratio greater than 1.8, and were diluted to around $500 \mathrm{ng} \cdot \mu \mathrm{L}^{-1}$.

\section{5. $P C R$}

PCR was used to identify transgenic positive and negative $F_{1}$ families. Embryos were sampled from all families at $24 \mathrm{hpf}$, and DNA was extracted using QIAGEN ${ }^{\circledR}$ buffer set, following the procedures of the QIAGEN ${ }^{\circledR}$ genomic DNA handbook (2012), then purified and diluted to work as PCR template. Three sets of 3 pooled embryos were tested for each family for possession of transgenes. Eight pairs of primers were designed to amplify specific segments of the FRMwg plasmid bone structure sequence corresponding to the two different promoter sequences and the four different knockdown sequences (Table 4). PCR products were gel electrophoresed to identify positive families.

\subsection{Real-Time PCR}

RNAs were reverse transcribed into cDNAs by iScript Synthesis Kit (Bio-Rad, catalog \#: 170-8891). Each reaction consisted of a total volume of $10 \mu \mathrm{L}$ containing $4.0 \mu \mathrm{L}$ iScript reaction mix, $1.0 \mu \mathrm{L}$ iScript reverse transcriptase, $500 \mathrm{ng}$ RNA template, and water to reach the $10.0 \mu \mathrm{L}$ volume. The reaction followed the protocol: $5 \mathrm{~min}$ at $25^{\circ} \mathrm{C}, 30 \mathrm{~min}$ at $42^{\circ} \mathrm{C}, 5 \mathrm{~min}$ at $85^{\circ} \mathrm{C}$. cDNAs were then diluted to $200 \mathrm{ng} \cdot \mu \mathrm{L}^{-1}$.

qPCR was conducted with a C1000 Thermo-Cycler (Bio-Rad, USA) by using the SsoFast ${ }^{\mathrm{TM}}$ EvaGreen ${ }^{\circledR}$ supermix kit (Bio-Rad, catalog: \#172-5201). Reactions were performed in a $10 \mu \mathrm{L}$ total reaction volume $\left(9.0 \mu \mathrm{L}\right.$ mix and $1.0 \mu \mathrm{L}$ cDNA). The mix contained $1.0 \mu \mathrm{L}$ of each primer $\left(5 \mu \mathrm{mol} \cdot \mu \mathrm{L}^{-1}\right)$, $4.0 \mu \mathrm{L}$ SsoFast EvaGreen supermix, and 3.0 $\mu \mathrm{L}$ RNase/DNase-free water. The same cycling conditions were used for all the tested samples: (1) denaturation, $95^{\circ} \mathrm{C}$ for $30 \mathrm{~s}$; (2) 40 cycles of $95^{\circ} \mathrm{C}$ for $5 \mathrm{~s}$, and $57^{\circ} \mathrm{C}$ for $15 \mathrm{~s}$; followed by (3) melting curve analysis, $5 \mathrm{~s}$ at $65^{\circ} \mathrm{C}$, then up to $95^{\circ} \mathrm{C}$ with a $0.1^{\circ} \mathrm{C}$ temperature increase every second. The mRNA levels of all the samples were normalized to the levels of the non-transgenic control sample of the same time point. Ribosome $18 \mathrm{~s}$ mRNA was used as a 
reference gene. Crossing-point $(\mathrm{Ct})$ values were exported into Excel sheet from Bio-Rad CRX Manager (Version 1.6.541.1028, 2008). Su et al. [32] designed primers used for qPCR for the current experiment.

Table 4. List of primers used for PCR identification of transgenic channel catfish (Ictalurus punctatus) for 8 primordial germ cell knockdown constructs. Construct components were: ADSS, zebrafish adenylosuccinate synthase 2 (adss2) promoter; RM, zebrafish racemase promoter; N1, 5' end ds-shRNA targeting channel catfish nanos gene; N2, 3' end ds-shRNA targeting channel catfish nanos gene; cDNA, full-length cDNA sequence of channel catfish nanos gene; DND, ds-shRNA targeting channel catfish dead end gene.

\begin{tabular}{cc}
\hline Primers & Sequence $\left(\mathbf{5}^{\prime}-\mathbf{3}^{\prime} \mathbf{)}\right.$ \\
\hline Forward primer for insulator & ACACTGTCCTTGGTATCAGCA \\
Reverse primer for insulator & ACACCTCCTTGATCCTGTGC \\
Forward primer for ocean pout terminator & TGCCCAAATTTCCTGCCTGA \\
Reverse primer for ocean pout terminator & TGCCTGTGAGGGTGACAAAA \\
Forward primer for $a d s s 2$ promoter & CCGCCAAAATACGACTG \\
Reverse primer for adss 2 promoter & TAAGCGAGGGAACAACG \\
Forward primer for racemase promoter & TACAACACCCACAATCCC \\
Reverse primer for racemase promoter & CACCGTAACAAAGAAACTCC \\
Forward primer for N1 & ATGACTCGCGATGGTGTTTT \\
Reverse primer for N1 & CATACTGGGGTGTTTGCTGA \\
Forward primer for N2 & CACTCGCTAGAGTGGGGTTC \\
Reverse primer for N2 & TCATACTGGGGTGTTTGCTG \\
Forward primer for cDNA & GAACCCCACTCTCACACTCG \\
Reverse primer for cDNA & AGACCCGCACCTGTAACATG \\
Forward primer for DND & TAGCGCCGCTCTACGAGT \\
Reverse primer for DND & TCATACTGGGGTGTTTGCTG \\
\hline
\end{tabular}

\subsection{Spawning Evaluation}

From 2012 to 2015, $99 \mathrm{P}_{1}$ females electroporated with (exposed to) the salt sensitive sterilization constructs as one-cell embryos were injected with LHRHa to induce spawning or were evaluated for spawning readiness. A total of 58 were from the untreated group and 41 were from the treated group (Table 1). The spawning rates were recorded by transgenic treated and untreated, 2 promoter and 4 knockdown strategies, resulting in 16 groups in total. The records were then summarized and analyzed to reveal the spawning rate differences between knockdown strategies, between promoters and between treated and untreated groups.

\subsection{Statistical Analysis}

Fisher's Exact Test and Fisher's Multi-treatment Exact Test were used to compare rates of sexual maturity and spawning between and among the different treatment groups. REST (Relative Expression Software Tool) [47], using Pairwise Fixed Reallocation Randomization Test, was applied to compare the RNA expression level of the three PGC migration marker genes (nanos, vasa and dead end) among the treated group, untreated group and non-transgenic group and $18 \mathrm{~S}$ was used as reference gene for this evaluation. Group means were used to express differences in expression between untreated, non-transgenic and treated samples. Statistical significance was performed by randomization test with 2000 randomizations per test $(p<0.05)$.

Acknowledgments: This work was partially funded by the United States Department of AgricultureBiotechnology Risk Assessment Grant Program (grant No. 2009-33522-05774). The FRMwg plasmid was supplied by Patrick Gibbs from the Rosenstiel School of Marine and Atmospheric Science, University of Miami, Florida.

Author Contributions: Experimental design and project concept: R. D., B. S. and H.L. Molecular data collection and analysis: H. L. and B. S. Field work, brood stock preparation, spawning, hatching and growth experiments and data collection: H. L., B. S., G. Q., Z. Y., A. A., D. P., M. S., R. O., K. V., D. D., D. R., D. Z., N. A. Manuscript writing: H. L. and R. D. 
Conflicts of Interest: The authors declare no conflict of interest.

\section{References}

1. AquaBounty Technologies. Available online: https://aquabounty.com/innovation/technology (accessed on 25 January 2017).

2. Devlin, R.H.; Sundström, L.F.; Leggatt, R.A. Assessing ecological and evolutionary consequences of growth-accelerated genetically engineered fishes. BioScience 2015, 65, 685-700. [CrossRef]

3. Rasmussen, R.S.; Morrissey, M.T. Biotechnology in aquaculture: Transgenics and polyploidy. Compr. Rev. Food Sci. Food Saf. 2007, 6, 2-16. [CrossRef]

4. Mair, G.C.; Nam, Y.K.; Solar, I. Environmental Risk Assessment of Genetically Modified Organisms, Volume 3. In Methodologies for Transgenic Fish; School of Biological Sciences, Flinders University: Adelaide, Australia, 2007.

5. Molyneaux, K.; Wylie, C. Primordial germ cell migration. Int. J. Dev. Biol. 2004, 48, 537-544. [CrossRef] [PubMed]

6. Köprunner, M.; Thisse, C.; Thisse, B.; Raz, E. A zebrafish nanos-related gene is essential for the development of primordial germ cells. Genes Dev. 2001, 15, 2877-2885. [PubMed]

7. Li, M.; Hong, N.; Xu, H.; Yi, M.; Li, C.; Gui, J.; Hong, Y. Medaka vasa is required for migration but not survival of primordial germ cells. Mech. Dev. 2009, 126, 366-381. [CrossRef] [PubMed]

8. Richardson, B.E.; Lehmann, R. Mechanisms guiding primordial germ cell migration: Strategies from different organisms. Nat. Rev. Mol. Cell Biol. 2010, 11, 37-49. [CrossRef] [PubMed]

9. Saito, T.; Fujimoto, T.; Maegawa, S.; Inoue, K.; Tanaka, M.; Arai, K.; Yamaha, E. Visualization of primordial germ cells in vivo using GFP-nos1 3'UTR mRNA. Int. J. Dev. Biol. 2006, 50, 691-699. [CrossRef] [PubMed]

10. Wong, T.T.; Collodi, P. Inducible sterilization of zebrafish by disruption of primordial germ cell migration. PLoS ONE 2013, 8, e68455. [CrossRef] [PubMed]

11. Slanchev, K.; Stebler, J.; de la Cueva-Méndez, G.; Raz, E. Development without germ cells: The role of the germ line in zebrafish sex differentiation. Proc. Nat. Acad. Sci. USA 2005, 102, 4074-4079. [CrossRef] [PubMed]

12. Weidinger, G.; Stebler, J.; Slanchev, K.; Dumstrei, K.; Wise, C.; Lovell-Badge, R.; Thisse, C.; Thisse, C.; Raz, E. Dead end, a novel vertebrate germ plasm component, is required for zebrafish primordial germ cell migration and survival. Curr. Biol. 2003, 13, 1429-1434. [CrossRef]

13. Fan, L.; Moon, J.; Wong, T.T.; Crodian, J.; Collodi, P. Zebrafish primordial germ cell cultures derived from vasa::RFP transgenic embryos. Stem Cells Dev. 2008, 17, 585-597. [CrossRef] [PubMed]

14. Yoon, C.; Kawakami, K.; Hopkins, N. Zebrafish vasa homologue RNA is localized to the cleavage planes of 2and 4-cell-stage embryos and is expressed in the primordial germ cells. Development 1997, 124, 3157-3165. [PubMed]

15. Herpin, A.; Rohr, S.; Riedel, D.; Kluever, N.; Raz, E.; Schartl, M. Specification of primordial germ cells in medaka (Oryzias latipes). BMC Dev. Biol. 2007, 7, 3. [CrossRef] [PubMed]

16. Braat, A.K.; van de Water, S.; Korving, J.; Zivkovic, D. A zebrafish vasa morphant abolishes vasa protein but does not affect the establishment of the germline. Genesis 2001, 30, 183-185. [CrossRef] [PubMed]

17. Gavis, E.R.; Lunsford, L.; Bergsten, S.E.; Lehmann, R. A conserved 90 nucleotide element mediates translational repression of nanos RNA. Development 1996, 122, 2791-2800. [PubMed]

18. Kedde, M.; Strasser, M.J.; Boldajipour, B.; Vrielink, J.A.; Slanchev, K.; le Sage, C.; Nagel, R.; Voorhoeve, P.M.; van Duijse, J.; Orom, U.A.; et al. RNA-binding protein Dnd1 inhibits microRNA access to target mRNA. Cell 2007, 131, 1273-1286. [CrossRef] [PubMed]

19. Saurabh, S.; Vidyarthi, A.S.; Prasad, D. RNA interference: Concept to reality in crop improvement. Planta 2014, 239, 543-564. [CrossRef] [PubMed]

20. Daneholt, B. Advanced information: RNA interference. The Nobel Prize in Physiology or Medicine 2006. Archived from the Original on 20 January 2007.

21. Thresher, R.; Grewe, P.; Patil, J.G.; Whyard, S.; Templeton, C.M.; Chaimongol, A.; Hardy, C.; Hinds, L.A.; Dunham, R.A. Development of repressible sterility to prevent the establishment of feral populations of exotic and genetically modified animals. Aquaculture 2009, 290, 104-109. [CrossRef] 
22. Bernick, E.P.; Zhang, P.J.; Du, S. Knockdown and overexpression of Unc-45b result in defective myofibril organization in skeletal muscles of zebrafish embryos. BMC Cell Biol. 2010, 11, 70. [CrossRef] [PubMed]

23. Prelich, G. Gene Overexpression: Uses, mechanisms, and interpretation. Genetics 2012, 190, 841-854. [CrossRef] [PubMed]

24. Thresher, R.; Hinds, L.A.; Hardy, C.; Whyard, S.; Vignarajan, S.; Grewe, P.; Patil, J. Repressible Sterility of Animals. U.S. Patent 20050071891, 31 March 2005.

25. Borode, A.O.; Balogun, A.M.; Omoyeni, B.A. Effect of salinity on embryonic development, hatchability, and growth of african catfish, Clarias gariepinus, eggs and larvae. J. Appl. Aquac. 2008, 12, 89-93. [CrossRef]

26. Swann, L.; Fitzgerald, S. The Use and Application of Salt in Aquaculture; Purdue University: West Lafayette, IN, USA, 1992.

27. Hoshijima, K.; Hirose, S. Expression of endocrine genes in zebrafish larvae in response to environmental salinity. J. Endocrinol. 2007, 193, 481-491. [CrossRef] [PubMed]

28. Powers, D.A.; Cole, T.; Creech, K.; Chen, T.T.; Lin, C.M.; Kight, K.; Dunham, R.A. Electroporation: A method for transferring genes into the gametes of zebrafish, Danio rerio, channel catfish, Ictalurus punctatus, and common carp, Cyprinus carpio. Mol. Mar. Biol. Biotechnol. 1992, 1, 301-309. [PubMed]

29. Cheng, Q.; Su, B.F.; Qin, Z.K.; Weng, C.C.; Yin, F.; Zhou, Y.G.; Fobes, M.; Rex, D.A. Interaction of diet and the masou salmon $\Delta 5$-desaturase transgene on $\Delta 6$-desaturase and stearoyl-CoA desaturase gene expression and N-3 fatty acid level in common carp (Cyprinus carpio). Transgen. Res. 2014, 23, 729-742. [CrossRef] [PubMed]

30. Gibbs, P.D.; Schmale, M.C. GFP as a genetic marker scorable throughout the life cycle of transgenic zebra fish. Mar. Biotechnol. 2000, 2, 107-125. [PubMed]

31. Xu, H.; Lim, M.; Dwarakanath, M.; Hong, Y. Vasa identifies germ cells and critical stages of oogenesis in the asian seabass. Int. J. Biol. Sci. 2004, 10, 225-235. [CrossRef] [PubMed]

32. Su, B.F.; Shang, M.; Grewe, P.M.; Patil, J.G.; Peatman, E.; Perera, D.A.; Cheng, Q.; Li, C.; Weng, C.C.; Li, P.; et al. Suppression and restoration of primordial germ cell marker gene expression in channel catfish, Ictalurus punctatus, using knockdown constructs regulated by copper transport protein gene promoters: Potential for reversible transgenic sterilization. Theriogenology 2015, 84, 1499-1512. [CrossRef] [PubMed]

33. Su, B.F.; Peatman, E.; Shang, M.; Thresher, R.; Grewe, P.; Patil, J.; Pinkert, C.A.; Irwin, M.H.; Li, C.; Perera, D.A.; et al. Expression and knockdown of primordial germ cell genes, vasa, nanos and dead end in common carp (Cyprinus carpio) embryos for transgenic sterilization and reduced sexual maturity. Aquaculture 2014, 420-421, 72-84. [CrossRef]

34. Zhang, D. Transgenic Disruption of Aromatase Using the Daughterless Construct to Alter Sex Ratio in Common Carp, Cyprinus carpio. Master's Thesis, Auburn University, Auburn, AL, USA, 1 August 2016.

35. Saxena, S.; Jonsson, Z.O.; Dutta, A. Small RNAs with imperfect match to endogenous mRNA repress translation. J. Biol. Chem. 2003, 278, 44312-44319. [CrossRef] [PubMed]

36. Scacheri, P.C.; Rozenblatt-Rosen, O.; Caplen, N.J.; Wolfsberg, T.G.; Umayam, L.; Lee, J.C.; Hughes, C.M.; Shanmugam, K.S.; Bhattacharjee, A.; Meyerson, M.; et al. Short interfering RNAs can induce unexpected and divergent changes in the levels of untargeted proteins in mammalian cells. Proc. Nat. Acad. Sci. USA 2004, 101, 1892-1897. [CrossRef] [PubMed]

37. Slanchev, K.; Stebler, J.; Goudarzi, M.; Cojocaru, V.; Weidinger, G.; Raz, E. Control of Dead end localization and activity-Implications for the function of the protein in antagonizing miRNA function. Mech. Dev. 2009, 126, 270-277. [CrossRef] [PubMed]

38. Raz, E. The function and regulation of vasa-like genes in germ-cell development. Gen. Biol. 2000, 1, 1017.1-1017.6. [CrossRef] [PubMed]

39. Reynolds, N.; Collier, B.; Maratou, K.; Bingham, V.; Speed, R.M.; Taggart, M.; Semple, C.A.; Gray, N.K.; Cooke, H.J. Dazl binds in vivo to specific transcripts and can regulate the pre-meiotic translation of Mvh in germ cells. Hum. Mol. Genet. 2005, 14, 3899-3909. [CrossRef] [PubMed]

40. Kato, Y.; Katsuki, T.; Kokubo, H.; Masuda, A.; Saga, Y. Dazl is a target RNA suppressed by mammalian NANOS2 in sexually differentiating male germ cells. Nat. Commun. 2016, 7, 11272. [CrossRef] [PubMed]

41. PIPs: Human protein-protein interactions prediction database. Available online: http://www.compbio. dundee.ac.uk/www-pips/evidence.jsp?Prot=IPI00395811\&Prot1=21244\&Prot2=10958\&Interactions= Prot\&LR=0.025\&modules $=$ on (accessed on 2 May 2017).

42. Perry, W.G. Note on the spawning of blue and channel catfish in brackish water ponds. Prog. Fish Cultur. 1973, 35, 164-166. [CrossRef] 
43. Perera, D.A. Studies for Improvement of Reproductive Biotechnology for Production of Channel Catfish (Ictalurus punctatus) Female X Blue Catfish (Ictalurus furcatus) Male Hybrid Embryos. Ph.D. Thesis, Auburn University, Auburn, AL, USA, 2012.

44. Su, B.F.; Perera, D.A.; Zohar, Y.; Abraham, E.; Stubblefield, J.; Fobes, M.; Beam, R.; Argue, B.; Ligeon, C.; Padi, J.; et al. Relative effectiveness of carp pituitary extract, luteininzing hormone releasing hormone analog (LHRHa) injections and LHRHa implants for producing hybrid catfish fry. Aquaculture 2013, 372-375, 133-136. [CrossRef]

45. Chatakondi, N.G.; Yant, D.R.; Dunham, R.A. Final Report-Spawning and Hatchery Technology to Improve Hybrid Catfish Fry Production; SBIR project No. 2002-00384; U.S. Department of Agriculture (USDA): Washington, DC, USA, 2005.

46. Armstrong, J.B.; Duhon, S.T.; Malacinski, G.M. Raising the Axolotl in Captivity. In Developmental Biology of the Axolotl; Armstrong, J.B., Malacinski, G.M., Eds.; Oxford University Press: New York, NY, USA, 1989; pp. 220-227.

47. Pfaffl, M.W.; Horgan, G.W.; Dempfle, L. Relative expression software tool (REST) for group-wise comparison and statistical analysis of relative expression results in real-time PCR. Nucleic Acids Res. 2002, 30, e36. [CrossRef] [PubMed]

(C) 2017 by the authors. Licensee MDPI, Basel, Switzerland. This article is an open access article distributed under the terms and conditions of the Creative Commons Attribution (CC BY) license (http:/ / creativecommons.org/licenses/by/4.0/). 